\title{
MUTUAL FUNDS AND THE REGULATORY CAPTURE OF THE SEC
}

\author{
Stewart L. Brown, Ph.D., CFA*
}

Regulatory agencies are created to act in the public interest but often end up acting in the interests of those regulated. This is known as regulatory capture. The mutual fund industry is the custodian of massive levels of wealth of the investing public and is regulated by the Securities Exchange Commission ("the SEC"). Mutual fund assets are currently in the neighborhood of $\$ 16$ trillion and these assets generate revenues in excess of $\$ 100$ billion per year for the firms that manage mutual funds. The investment management industry is incentivized to influence the regulators by whatever means available to maximize profits for their owners. This paper documents how the investment management industry has captured the SEC in certain key policy areas. As a result, the industry is able to siphon off billions of dollars per year in excessive and often hidden fees. The SEC has within its power to unilaterally blunt the worse abuses if it were willing to act in the public interest.

* Emeritus Professor of Finance, Florida State University, B.S.B.A., 1970; M.B.A., 1971; Ph.D., 1974, University of Florida; CFA. The author is grateful to John Freeman, David Rasmussen, and Mary McCormick for assistance on earlier drafts of this paper. Remaining mistakes are the sole responsibility of the author. 
INTRODUCTION 702

I. REGULATORY CAPTURE.

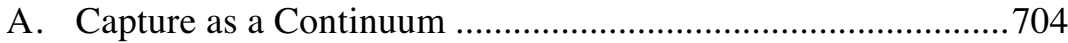

B. Broad and Narrow Regulatory Capture ..................................706

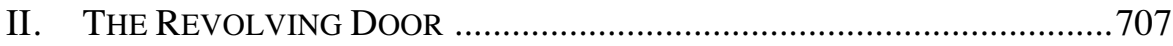

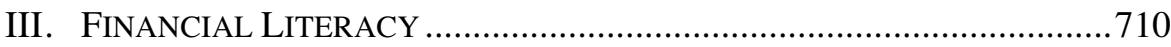

IV. BROAD REGULATORY CAPTURE - ADVISORY FEES, DISTRIBUTION FEES, AND SOFT DOLLARS ..................................... 712

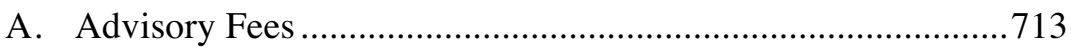

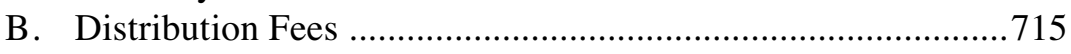

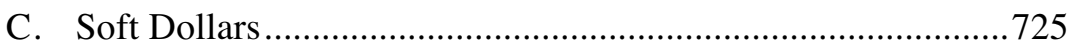

V. NARRow REgulatory CAPTURE - FEe Disclosure,

DISTRIBUTION FEES, SOFT DOLLAR COMMISSIONS, AND

TRADING COSTS.

A. Fee Disclosure - Undisclosed Dollar Expenses ......................730

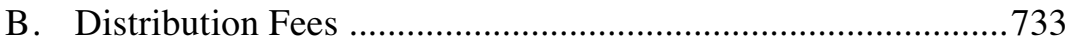

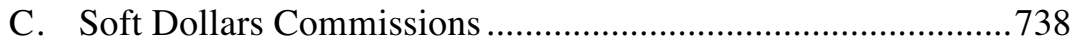

D. Disclosure of Trading Costs .................................................... 742

VI. FAILURE OF COMPREHENSIVE MUTUAL FUND REFORM

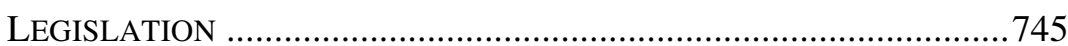

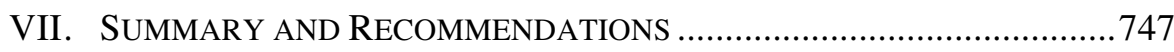

\section{INTRODUCTION}

Mutual fund assets currently total about $\$ 16$ trillion. ${ }^{1}$ The companies that manage mutual funds collect more than $\$ 100$ billion per year in fees. ${ }^{2}$ At present, about ninety million investors own mutual funds ${ }^{3}$ that are theoretically highly regulated by the Securities and Exchange Commission. ${ }^{4}$ One of the principal missions of the SEC is to protect investors. ${ }^{5}$ Regulatory agencies, created to act in the public interest, often

1. Trends in Mutual Fund Investing December 2016, Inv. Co. Inst., https://www.ici.org/research/stats/trends/trends_12_16 [https://perma.cc/BA7N-9M38] (last visited Feb. 1, 2017).

2. Morningstar, Inc. did a fee study in 2015 , where it found that the asset weighted expense ratio across all funds was $0.64 \%$. Multiplying 0.0064 times $\$ 16$ trillion yields annual amounts paid to the investment management industry of $\$ 104$ billion. Michael Rawson \& Ben Johnson, 2015 Fee Study: Investors Are Driving Expense Ratios Down, MORNINGSTAR 1 (Mar. 12, 2015), https://news.morningstar.com/pdfs/2015_fee_study.pdf [https://perma.cc/7LC4-7G3A].

3. Id.

4. 17 C.F.R. $\S 270$ (1940).

5. About the SEC: What We Do, U.S. Sec. \& ЕхсH. Comm'N (June 10, 2013), 
end up acting directly or indirectly in the interests of those they regulate. This concept of "Regulatory Capture" is rooted in the economics and political science literature. George Stigler, in his "Theory of Economic Regulation," argued that, "as a rule, regulation is acquired by the industry and is designed and operated primarily for its benefit." He discusses how firms in regulated industries often use regulation to restrict entry and earn monopoly profits.

Stigler, a Nobel Laureate, observed that the government's special resource is the power to coerce, ${ }^{8}$ and interest groups that can convince the government to use its coercive power for their benefit can earn economic rents at the expense of others. ${ }^{9}$ Stigler was influenced by the public choice theories advanced by Mancur Olson. ${ }^{10}$ A principal insight of Olson in his "The Logic of Collective Action" is that some groups have a larger impact on government policies than others. ${ }^{11}$ In a democratic system, people with common interests generally will band together to achieve common goals. ${ }^{12}$ However, if the benefits of a political outcome are concentrated in the hands of a few and the costs are diffused among many, the beneficiaries are motivated to influence the political process in their favor. ${ }^{13}$ At the same time, those who bear the costs have little incentive to organize to protect their interests. ${ }^{14}$

The mutual fund industry offers a textbook illustration of Olson's insights. It has been observed that the investment management industry overcharges investors by about $\$ 35$ billion annually in the form of excess advisory fees. ${ }^{15}$ If this observation is correct, the $\$ 35$ billion is spread among ninety million investors so that on average each investor pays about $\$ 400$ per year in excess fees. Yet the fifty largest investment management firms would each benefit by about $\$ 588$ million per year. ${ }^{16}$ Certainly, the

http://www.sec.gov/about/whatwedo.shtml [https://perma.cc/VU78-TZ6X].

6. George J. Stigler, The Theory of Economic Regulation, 2 Bell J. ECON. \& MGMT. SCI. 3 (1971).

7. Id. at 5 .

8. Id. at 4 .

9. Id.

10. Mancur Olson, The Logic of Collective Action (1965).

11. See id. at 3, 127-28 ('[S]mall 'special interest' groups, the 'vested interests' have disproportionate power.... The privileged and intermediate groups often triumph over the numerically superior forces in the latent or large groups because the former are generally organized and active while the latter are normally unorganized and inactive.").

12. Id . at 5 .

13. Id. at 3 .

14. Id. at 165-66.

15. Stewart Brown, Mutual Fund Advisory Fee Litigation: Some Analytical Clarity, 16 J. Bus. \& SEC. L. 329, 399-400 (2016).

16. Based on information from Morningstar Direct (a proprietary database service of 
motivation exists for the investment management industry to capture the SEC. Capture, in this case, is an especially pernicious outcome because small cost increments subtracted from the accounts of millions of individual investors have a large impact when compounded over long time periods.

This paper presents compelling evidence that the SEC has been effectively captured by the mutual fund industry. At the same time, the agency may be partially exonerated from blame because some of the important examples of capture illustrated were imposed on it by external factors, which are generally associated with political intrusion into the regulatory process.

This paper is divided into seven parts. Part I explores the literature on regulatory capture. Part II discusses the revolving door between the SEC and the financial and investment management industry. Part III explores characteristics of mutual fund investors whom the SEC is pledged to protect. In Part IV, the paper presents examples of forces external to the SEC that have resulted in excessive and hidden fees on the assets of mutual fund investors. Part V examines regulatory outcomes imposed directly by the SEC and how they demonstrate clear deference to the investment management industry. Finally, Part VI details the failure of comprehensive mutual fund reform in 2004, and Part VII summarizes the paper and makes recommendations to correct some of the most egregious shortcomings of the SEC's regulatory regime.

\section{REGULATORY CAPTURE}

\section{A. Capture as a Continuum}

The Stigler analysis of regulatory capture, developed in the early 1970s, tended to see capture as an all-or-nothing proposition effectively capturing most regulated industries. ${ }^{17}$ A more recent and sophisticated analysis tends to see capture as a continuum. Daniel Carpenter and David A. Moss explored the concept, defining regulatory capture as "the result or process by which regulation, in law or application, is consistently or

Morningstar, Inc.) and some data calculations from it, the fifty largest firms controlled about $84 \%$ of mutual fund assets. See generally Alina Lamy, Morningstar Direct ${ }^{\text {SM }}$ U.S. Asset Flows Update, MORNINGSTAR (Jan. 15, 2016), http://corporate.morningstar.com /US/documents/AssetFlows/AssetFlowsJan2016.pdf [https://perma.cc/VC34-WGJF] (presenting various numerical data regarding U.S. asset flows through the end of 2015). So, $84 \%$ of $\$ 35$ billion divided by 50 yields an average of $\$ 588$ million in excess fees per firm.

17. Stigler, supra note 6 , at 3. 
repeatedly directed away from the public interest and towards the interests of the regulated industry, by the action or intent of the industry itself." ${ }^{18}$

They find that:

The regulatory world is one of shades of gray. Yet capture scholarship does not typically discriminate among these shades in ways that enable informed advice on the marginal value of regulatory (or deregulatory) policy options.... However, the essential idea is that policymakers are for sale, and that regulatory policy is largely purchased by those most interested and able to buy it, remains central to the literature. ${ }^{19}$

Carpenter and Moss differentiate between "strong" and "weak" capture:

Strong capture violates the public interest to such an extent that the public would be better served by either (a) no regulation of the activity in question ... or (b) comprehensive replacement of the ... agency in question. ... Weak capture, by contrast, occurs when special interest influence compromises the capacity of regulation to enhance public interest, but the public is still being served by regulation, relative to the baseline of no regulation. ${ }^{20}$

Carpenter and Moss conclude that "although capture can (and does) take a range of forms, credible evidence of strong and/or pervasive capture is difficult to find, and we suspect that cases of both are quite rare."21 Similarly, Dal Bó finds "(unfortunately scarce) evidence regarding the link between political influence and regulatory outcomes.",22

Neither Carpenter and Moss nor Dal Bó have examined the mutual fund industry, where trillions of invested dollars have invited a systematic violation of the public trust involving billions of dollars of excess and hidden fees per year. Some of the evidence presented here is explicitly political in nature and neither subtle nor abstract. Other evidence shows a consistent and pervasive bias in favor of the mutual fund industry and against the interests of the investing public.

18. Daniel Carpenter \& David A. Moss, eds., Preventing Regulatory Capture, SPECIAL INTEREST INFLUENCE AND HOW TO LIMIT IT 13 (2014).

19. Id. at 9 .

20. Id. at 11-12.

21. Id. at 454 .

22. Ernesto Dal Bó, Regulatory Capture: A Review, 22 OXFORD REV. ECON. POL'Y 203, 216 (2006). 


\section{B. Broad and Narrow Regulatory Capture}

Carpenter and Moss define regulatory capture as the process by which regulation, "in law or application," "is directed away from the public interest." 23 According to Dal Bó, regulatory capture may receive both a broad and narrow interpretation. Broadly interpreted, regulatory capture is "the process through which special interests affect state intervention in any of its forms," i.e., taxes, monetary policy, legislation, etc. ${ }^{24}$ Under a narrow interpretation, regulatory capture "is specifically the process through which regulated monopolies end up manipulating the state agencies that are supposed to control them." 25 Thus, under the broad interpretation, political influence may impact regulation because the legislature passes laws contrary to the public interest, which the agency must then interpret and administer. ${ }^{26}$ Similarly, under the narrow interpretation, regulators may interpret legislation in a manner contrary to the public interest. ${ }^{27}$ In what follows, the differentiation of broad and narrow capture holds up reasonably well but not perfectly. In some cases, the distinction is blurred. Both forms are consistent with the Carpenter and Moss definition of regulatory capture, and the "shades of gray" mentioned by them are on full display.

The broad regulatory capture documented here is overtly political in nature. The industry achieves its goals by influencing politicians or political appointees in a manner harmful to the public interest. The influence may involve shaping legislation to reduce or eliminate adverse regulation, or it may involve petitioning political appointees directly to achieve favorable outcomes. In either case, the agency is effectively captured because it must act in the interest of the industry and agency personnel are prevented from acting in the public interest. Broad capture is consistent with the Carpenter and Moss definition because the agency regulation or the lack thereof is directed away from the public interest by law or application.

The examples of broad regulatory capture illustrated below are relatively straightforward and easy to identify. The political pressure involved is explicit and unambiguous. Narrow regulatory capture is different in that it is often ambiguous, difficult to identify with confidence, and also subject to the shades of gray mentioned by Carpenter and Moss. ${ }^{28}$

23. CARPENTER \& Moss, supra note 18 , at 13.

24. Dal Bó, supra note 22, at 203.

25. Id.

26. Id. at 216 .

27. Id. at 211-13.

28. CARPENTER \& Moss, supra note 18 , at 9. 
The traditional notion of regulatory capture has the self-interest of the regulators as its primary motivation; however sometimes there are other factors that intervene to cloud the issue. In regulatory settings, there is often a range of plausible disagreement concerning policy. For instance, deregulation of the financial system pre-crisis had a plausible free market rationale. It was only after the fact that it became clear regulatory errors were committed. ${ }^{29}$

Motivations other than just self-interest may cause regulators to favor industry at the expense of the public. Kwak discusses cultural capture wherein regulators come to absorb the world view and narrative of the industry they regulate. The mechanism has to do with several factors including identification with an in-group and perceived social, economic, and intellectual status of the regulated. Finally, the development of personal relationships between the regulators and regulated may cause a conscious or unconscious bias in favor of regulated individuals and the industry that employs them. ${ }^{30}$

Potential employment of regulators in the regulated industry is a motivation for regulators to favor the regulated. When present, it is clearly associated with the self-interest of the regulator.

\section{THE REVOLVING DOOR}

The back-and-forth of SEC employees to and from the financial sector, not just the mutual fund industry, is massive. The Project on Government Oversight (POGO) has found that:

[F]rom 2001 through 2010, 419 former SEC employees filed at least 1,949 disclosure statements saying they planned to represent clients or new employers in matters pending at the SEC. . . The 1,949 statements are just the tip of the iceberg, because former employees are only required to file them during the two-year period immediately after they leave the agency. POGO found that many former SEC employees have helped businesses get a break from the agency. ${ }^{31}$

29. See James Kwak, Cultural Capture and the Financial Crisis, in Preventing Regulatory Capture, Special Interest Influence and How to Limit It 73 (Daniel Carpenter \& David A. Moss, eds., 2014) (explaining policies of deregulation that were favored pre-crisis by the financial sector to increase profits at the time but ultimately resulted in widespread loss).

30. Id. at 77-78.

31. Michael Smallberg, Dangerous Liaisons: Revolving Door at SEC Creates Risk of Regulatory Capture, ProjeCt ON Gov. Oversight 8 (Feb. 11, 2013), http://pogoarchives.org/ebooks/20130211-dangerous-liaisons-sec-revolving-door.pdf [https://perma.cc/C6GZ-H7T7]. 
The issue of former SEC employees attempting to influence the Commission on behalf of specific companies is a problem. However, the impact of former employees on overall policy is potentially serious, if not catastrophic. The POGO study illustrates a case in point: money market mutual funds.

Mary L. Schapiro, then-chairman of the SEC, was concerned about the potential systematic destabilizing risk of money market funds to the financial system. The genesis of this concern was the $\$ 300$ billion run on money market funds during the 2008 financial crisis. ${ }^{32}$ Ms. Schapiro proposed regulations to reduce the risk but failed to call for a vote of the Commission because three of the five commissioners had stated their opposition. $^{33}$

The opposition emerged because the SEC faced a barrage of lobbying activity on behalf of the money market industry by former SEC employees, including a former counsel to an SEC Commissioner and two former officials of the SEC Division of Investment Management. One of these was General Counsel of the Investment Company Institute (ICI) and the other was president and CEO of the Mutual Fund Directors Forum. Laura Unger, a former SEC Commissioner, also weighed in against the proposed regulation. ${ }^{34}$

The issue of new regulation of money market funds was finally decided when Commissioner Luis A. Aguilar weighed in against the proposed regulations. Commissioner Aguilar had formerly been executive vice president of Invesco, a money management firm. He had also worked as a corporate attorney where his practice involved representing mutual funds. ${ }^{35}$ Former SEC Chairman Levett called the SEC Money Fund punt a "National Disgrace.",36

32. Id. at 3; see Mary L. Schapiro, Chairman, U.S. Sec. \& Exch. Comm'n, Testimony on Perspectives on Money Market Mutual Fund Reforms (June 21, 2012), https://www.sec.gov/News/Testimony/Detail/Testimony/1365171489510

[https://perma.cc/D3M5-C2SU] (discussing the risks that money market funds pose to the financial system and the need to reform them).

33. Smallberg, supra note 31, at 3; Mary L. Schapiro, Chairman, U.S. Sec. \& Exch. Comm'n, Statement on Money Market Fund Reform (August 22, 2012), https://www.sec.gov/News/PressRelease/Detail/PressRelease/1365171484078 [https://perma.cc/AGC4-AUZJ].

34. Smallberg, supra note 31 , at 4 .

35. Id.; Luis A. Aguilar, Comm'r, U.S. Sec. \& Exch. Comm'n, Statement Regarding Money Market Funds (August 23, 2012) https://www.sec.gov/News/PublicStmt/Detail/ PublicStmt/1365171491044 [https://perma.cc/L5HA-VS94].

36. Laura Marcinek \& Tom Keene, Levitt Says SEC Money-Fund Punt a 'National Disgrace', BLOOMBerg (Aug. 23, 2012, 1:49 PM), https://www.bloomberg.com/news/201208-23/levitt-says-sec-inaction-on-funds-national-disgrace-tom-keene.html/ [https://perma.cc/JPM9-7TQC]. 
Thus, where money funds are concerned, it appears that the SEC had been captured at the commissioner level. However, the money fund situation is fraught with financial complexities and ambiguities. Reasonable people can disagree about proposed solutions. Commissioner Aguilar vigorously defended his position. When asked if his former position in the industry made him more sympathetic to the industry point of view, his answer was no. "'It gives me a level of knowledge,' he explained. 'I think my background gives me the ability to understand and put into context both the ... pros and cons of their arguments.",37

The SEC Division of Investment Management has responsibility for the mutual fund industry. The revolving door at the Division of Investment Management is also well documented. In 2003, Professor John Freeman made a Freedom of Information Act request for the names of former senior Division of Investment Management employees. He found that $80 \%$ of non-deceased senior employees who had left the SEC were "were either employed in-house by investment companies or advisers, the ICI, law firms, or accounting firms that provided services to mutual funds and fund sponsors." 38

Moreover, two recent Directors of the Division of Investment Management actually came from the investment management industry. Eileen Rominger, who served as Director of the SEC Division of Investment Management from February 2011 to June 2012, had been previously Chief Investment Officer of the portfolio management business in Goldman Sachs Asset Management. ${ }^{39}$ Norman Champ, Director from July, 2012 to January, 2015 was former Executive Vice President and General Counsel of Chilton Investment Company, an investment adviser to hedge funds and managed accounts. ${ }^{40}$ The fact that a regulator has connections to the investment management industry is not necessarily disqualifying. Indeed, in some cases it may be a necessity to understand the issues, however, it will always be potentially dangerous. As noted in the POGO study:

The close linkage between the regulators and the regulated can influence the culture, the values, and the mindset of the agencynot to mention its regulatory and enforcement policies-both

37. Smallberg, supra note 31 , at 5 .

38. John P. Freeman, The Mutual Fund Distribution Expense Mess, 32 J. CORP. L. 739, 743 (2007).

39. Press Release, U.S. Sec. \& Exch. Comm'n, SEC Names Eileen Rominger as Director of Division of Investment Management (Jan. 18, 2011), https://www.sec.gov/ news/press/2011/2011-14.htm [https://perma.cc/HYT7-UPTC].

40. Press Release, U.S. Sec. \& Exch. Comm'n, Investment Management Director Norm Champ to Leave SEC (Jan. 21, 2015), https://www.sec.gov/news/pressrelease/201511.html [https://perma.cc/BNN4-VTEQ]. 
from the bottom up and from the top down. To be sure, many employees may be immune to its influence and may explicitly reject it. But when so much of a regulatory agency's world view can be shaped by the industry it oversees, consciously or otherwise, the public has reason to be concerned. ${ }^{41}$

The concern is justified. There is every reason to believe that industry interests are shown great deference in the SEC's Division of Investment Management. It will be demonstrated next that the typical mutual fund investor is very much in need of protection. Subsequent sections will show that the public trust placed in the SEC to protect mutual fund investor interests has been systematically violated.

\section{FINANCIAL LITERACY}

Research on the financial literacy of the general population presents a bleak picture. In Annamaria Lusardi's exemplary review, she defines financial literacy as "the ability to process economic information and make informed decisions about financial planning, wealth accumulation, debt and pensions." ${ }^{42}$ She finds that "most individuals in the United States... cannot perform simple calculations and do not understand basic financial concepts such as interest compounding, the difference between nominal and real values and risk diversification."

In the Dodd-Frank Act, Congress instructed the SEC to conduct a study of investor financial literacy. ${ }^{44}$ The study was conducted in two parts. The SEC contracted with the Federal Research Division of the Library of Congress ${ }^{45}$ to conduct a review of the quantitative studies on the financial literacy of retail investors in the United States. ${ }^{46}$ The SEC also conducted extensive survey research of a large sample of investors. ${ }^{47}$

The SEC Study found results similar to those of Lusardi:

41. Smallberg, supra note 31 , at 7 .

42. Annamaria Lusardi, Financial literacy: Do People Know the ABCs of Finance?, 24 Pub. UndeRstANDING OF SCI. 260 (2015).

43. Id. at 261 .

44. Dodd-Frank Wall Street Reform and Consumer Protection Act, Pub. L. No. 111203, § 917, 124 Stat. 1376, 1836 (2010).

45. Office of Investor Educ. \& Advocacy, U.S. Sec. \& Exch. Comm'n, Study REgARDING FinANCIAL LITERACY AMONG INVESTORS 14 (2012), https://www.sec.gov/news/ studies/2012/917-financial-literacy-study-part1.pdf [https://perma.cc/5YAG-W66M] [hereinafter SEC Study].

46. FED. RESEARCH DIV., LIBRARY OF CONG., FinANCial Literacy Among Retail Investors In the United States (2011), https://www.sec.gov/news/studies/2012/917-financial-literacy-study-part2 .pdf [https://perma.cc/PL42-7PFN].

47. SEC Study, supra note 46. 
U.S. retail investors lack basic financial literacy. The studies demonstrate that investors have a weak grasp of elementary financial concepts.... Surveys also demonstrate that certain subgroups, including women, African-Americans, Hispanics, the oldest segment of the elderly population, and those who are poorly educated, have an even greater lack of investment knowledge than the average general population. ${ }^{48}$

The lack of financial literacy translates into well-documented, suboptimal investment behavior. The evidence is that investors in general make predictable mistakes: "They save too little, they trade too frequently, they buy high and sell low, they invest in fad instruments they do not understand, and they pay excessive fees." ${ }^{49}$

Of special interest is the finding that investors pay excessive fees. Studies strongly suggest that, of the information available to retail investors, mutual fund expenses are the best predictor of future returns. ${ }^{50}$ It has been shown that individual investors often buy funds with high fees ${ }^{51}$ and that substantial amounts have gone into index funds charging high fees (over $2 \%$ per year) for passive holdings of broad indexes, such as the Standard \& Poor's (S\&P) 500..$^{52}$ Thus, evidence pertaining to investor awareness of fees is especially important and within the purview of SEC regulation.

Empirical evidence supports the idea that fund investors are unaware of fees charged on funds. An SEC survey found that only 19\% of investors could give an estimate of expenses for their largest mutual fund. ${ }^{53} \mathrm{~A}$ minority of respondents (43\%) claimed to have known of the expenses of their largest funds at purchase and only $16 \%$ of survey respondents believed that higher expenses led to lower than average returns. ${ }^{54}$ Another study found that $84 \%$ of investors believe higher operating expenses mean better performance. ${ }^{55}$ Similarly, Wallison and Litan surveyed mutual fund

48. Id. at iii.

49. Jill E. Fisch \& Tess Wilkinson-Ryan, Why Do Retail Investors Make Costly Mistakes? An Experiment on Mutual Fund Choice, 162 U. PA. L. REv. 605, 606 (2014).

50. See, e.g., Russell Kinnel, Predictive Power of Fees: Why Mutual Fund Fees Are So Important, MORNINGSTAR (May 4, 2016), http://corporate1.morningstar.com/ ResearchArticle.aspx?documentId=752589 [https://perma.cc/R288-DJ7N].

51. Martin J. Gruber, Another Puzzle: The Growth in Actively Managed Mutual Funds, 51 J. Fin. 783, 784 (1996).

52. Edwin J. Elton, Martin J. Gruber \& Jeffrey A. Busse, Are Investors Rational? Choices Among Index Funds, 59 J. FIN. 261 (2004).

53. Gordon J. Alexander, Jonathan D. Jones \& Peter J. Nigro, Mutual Fund Shareholders: Characteristics, Investor Knowledge, and Sources of Information, 7 FIN. SERVS. REV. 301, 309 (1998).

54. Id.

55. Brad M. Barber, Terrance Odean \& Lu Zheng, Out of Sight, Out of Mind: The 
investors and asked them to rate (on a scale of one to ten) how informed they were about their own mutual fund investments. ${ }^{56}$ Only $21 \%$ of those investors rated their knowledge high (eight or above) ${ }^{57}$ Fewer than $10 \%$ of even that self-described knowledgeable subgroup "knew even approximately what they were paying as an advisory fee." 58

It is well known that compounded over time, even small percentage cost differences can result in dramatic differences in investment outcomes. Given the complexity of the investment world and documented lack of sophistication of most investors, it is important that the SEC foster simple, clear, and explicit cost disclosure. Unfortunately, as the examples in the following sections show, the SEC's efforts in this regard appear less than exemplary.

\section{BROAD REGULATORY CAPTURE - ADVISORY FEES, DISTRIBUTION FEES, AND SOFT DOLLARS}

The examples of broad capture documented here-advisory fees, distribution fees, and soft dollars-occurred between 1970 and 1980. The mutual fund investment management industry was able to preempt the SEC's initiative on advisory fees ${ }^{59}$ by influencing Congress in the 1970 Amendment ${ }^{60}$ to the 1940 Investment Company Act. ${ }^{61}$ Congress carved out an exemption for soft dollar commissions in $1975^{62}$ and the SEC allowed mutual funds to use assets to pay for distribution (marketing) in $1980 .^{63}$

Effects of Expenses on Mutual Fund Flows, 78 J. Bus. 2095, 2099 (2005).

56. Peter J. Wallison \& Robert E. Litan, Competitive Equity: A Better Way to ORGANIZE MutuAL FundS 73 (2007).

57. Id.

58. $I d$.

59. For more discussion on this, see Wharton SCH. OF FIn. \& COMMERCE, A STUDY OF Mutual FundS, H.R. REP. No. 87-2274 (1962) [hereinafter Wharton Report]; U.S. SEC. \& Exch. Comm'n, Public Policy Implications of Investment Company Growth, H.R. REP. No. 89-2337 (1966) [hereinafter PPI Study].

60. Investment Company Amendment Act of 1970, Pub. L. No. 91-547, 84 Stat. 1413 (1970) (codified as amended at 15 U.S.C. $\$ 80 a-35 b(2006)$ ).

61. Investment Company and Investment Advisers Act of 1940 ("ICA"), Pub. L. No. 76-678, 54 Stat. 789 (1940) (codified as amended at 15 U.S.C. $\$ \$ 80 a-1$ to -52 (2012)).

62. Securities Acts Amendments of 1975, Pub. L. No. 94-29, § 21, 89 Stat. 97, 160-61 (1975) (codified as amended at 15 U.S.C. § 78bb(e) (2012)).

63. Bearing of Distribution Expenses by Mutual Funds, 45 Fed. Reg. 73,898, 73,898 (Nov. 7, 1980) (to be codified at 17 C.F.R. pt. 270.12b-1). 


\section{A. Advisory Fees}

Mutual funds are unique. Unlike normal corporations, mutual funds do not have employees or physical assets. Effectively, the corporation or trust is a collection of contracts with certain service providers. First among the service providers is the manager of the fund's portfolio, an investment management firm. The investment management firm also creates the mutual fund and the fund is inextricably tied to it. Investment managers who create and manage mutual funds are often referred to as fund sponsors. Fund sponsors appoint the fund's trustees, and officers of the fund sponsor typically serve as board members. ${ }^{64}$

The fund sponsor is paid for the portfolio management services it provides. The portfolio management or advisory fee is a percentage rate charged annually against fund assets. ${ }^{65}$ For instance, if a fund has $\$ 1$ billion in assets and the advisory or management fee is fifty basis points $(0.5 \%)$, then the fund sponsor will receive annual revenues of $\$ 1$ billion times 0.005 or $\$ 5$ million. That amount, $\$ 5$ million, reduces the value of the fund-to-fund investors by $\$ 5$ million per year, thereby lowering the rate of return to fund investors. Thus, there is a fundamental conflict of interest between the fund sponsor and investors in the mutual fund. The fund is operated by the sponsor and is a captive entity - the mutual fund boards of directors or trustees essentially face a monopoly seller of advisory services. The U.S. Supreme Court has recognized that "the forces of arm's-length bargaining do not work in the mutual fund industry in the same manner as they do in other sectors of the American economy.",66

Because of this monopoly positioning, there is potential for a sponsor to overcharge the mutual fund for services provided. For example, the SEC commissioned a study by the Wharton School in 1962; it found substantial overcharging in the industry as a whole when mutual fund advisory fees were compared to advisory fees determined by competitive forces. ${ }^{67}$ In a follow-up study in 1966, the SEC itself documented similar results. ${ }^{68}$

64. See Jill E. Fisch, Rethinking the Regulation of Securities Intermediaries, 158 U. PA. L. REv. 1961, 1967-68 (2010) (covering how mutual funds are formed and operated); John Morley, The Separation of Funds and Managers: A Theory of Investment Fund Structure and Regulation, 123 YALE L.J. 1228, 1232 (2014) (discussing the organization of mutual funds).

65. Fisch, supra note 64, at 1971-72.

66. Jones v. Harris Assocs. L.P., 559 U.S. 335, 338 (2010), quoting S. Rep. No. 91184 , at 5 (1969).

67. Wharton Report, supra note 59, at 29 ("Advisory fee rates charged mutual funds tended to be substantially higher than those charged by the same advisers to the aggregate of their clients other than investment companies, for comparable asset levels.").

68. PPI Study, supra note 59, at 73. 
The SEC recommended that Congress impose a reasonableness standard enforceable in court. ${ }^{69}$ This recommendation was consistent with the observation that fund sponsors are in a monopoly position vis-a-vis the funds they manage and that competitive forces fail to operate on mutual fund fees. ${ }^{70}$

The Wharton and SEC reports presented Congress with a visible public problem that forced it to address the issue of fund fees. After several years of wrangling, Congress passed the 1970 amendment to the 1940 Investment Company Act. ${ }^{71}$ Rather than imposing a reasonableness standard, the amendment made fund sponsors fiduciaries with respect to fees received from funds and created a private cause of action on advisory fees. $^{72}$ On the surface, this represented a reasonable compromise. However, the language in the Senate Report made its true position clear:

In reporting this bill, your committee recognizes the importance of permitting adequate compensation and incentives so that men of ability and integrity will continue to be attracted to the mutual fund industry.... [Y] our committee has decided that there is an adequate basis to delete the express statutory requirement of "reasonableness," and to substitute a different method of testing management compensation. This bill states that the mutual fund investment advisor has a specific "fiduciary duty" in respect to management fee compensation.... This provision does not represent a finding by the committee as to the level of fees in the industry. Your committee does not believe itself qualified to make such judgments. Nor it is contemplated that the Commission will seek a general reduction of fees on an industrywide basis. ${ }^{73}$

The Senate wanted to facilitate the "adequate compensation and incentives so that men of ability and integrity will continue to be attracted to the mutual fund industry." 74 The SEC was clearly attempting to act in the public interest and conducted extensive research to support its position, yet the Senate basically ignored the findings of the Wharton School and its own securities regulator. Congress essentially told the SEC "hands off," neutering the SEC with respect to advisory fees going forward; for nearly fifty years, the SEC has indeed kept its hands off and the overcharging of

69. Id. at 143-47.

70. Wharton Report, supra note 59, at 30.

71. Investment Company Amendment Act of 1970, Pub. L. No. 91-547, 84 Stat. 1413 (1970) (codified as amended at 15 U.S.C. § 80a-35b (2006)).

72. 15 U.S.C. $\$ 80 a-35(b)(2012)$.

73. Investment Company Amendments Act of 1969, S. Rep. No. 91-184, at 4-7 (1969) (emphasis added).

74. Id. at 4 . 
mutual fund investors continues to this day. ${ }^{75}$ The 1970 amendments to the ICA represented a capitulation of the U.S. Congress to the investment management industry and forced surrender of the SEC on advisory fees. Special interest influences and the capture of the SEC are blatantly and explicitly on exhibit in a prime example of broad regulatory capture. ${ }^{76}$

\section{B. Distribution Fees}

If a manufacturer wants to sell more products, it will spend money on marketing. An informed judgment will be made that the short-term

75. Although the Senate imposed a fiduciary duty on fund sponsors with respect to fees, it handed the judicial system the problem of establishing a fiduciary standard to gauge fee excessiveness. The tone and language of the report leave no doubt as to which side of the argument the Senate favored - that of men of "ability and integrity" rather than the financial experts at Wharton and the SEC, thus endorsing the status quo. The courts also faced the problem that the Wharton- and SEC-documented inflated advisory fees did not disappear. Monopoly pricing power of fund sponsors and overcharging of advisory fees persists, as observed by Freeman and Brown in their updating of the Wharton and PPI studies. John P. Freeman \& Stewart L. Brown, Mutual Fund Advisory Fees: The Cost of Conflicts of Interest, 26 J. CORP. L. 609, 672 (2001). The industry was able to maintain fee levels with the aid of a brilliant legal strategy, which involved bringing to trial funds with anomalous expense categories that enabled the industry to fog up fee comparisons with fees actually determined at arm's length. Gartenberg v. Merrill Lynch Asset Mgmt., 694 F.2d 923 (2d Cir. 1982), recently reaffirmed by the U.S. Supreme Court in Jones v. Harris Assocs. L.P., 559 U.S. 335 (2010), which established an especially onerous fiduciary standard: "To be guilty of a violation ...., therefore, the adviser-manager must charge a fee that is so disproportionately large that it bears no reasonable relationship to the services rendered and could not have been the product of arm's-length bargaining." Gartenberg, 694 F.2d at 928 (emphasis added). The standard is so onerous that no plaintiff has ever received an award under $\$ 36 \mathrm{~B}$ of the ICA. See JAMES D. Cox ET AL., SECurities Regulation: CASES AND MATERIALS 1109 (6th ed. 2009) ("Subsequent litigation in excessive fee cases has resulted almost uniformly in judgments for the defendants"). The 1970 Act limited damages in fee cases to a one-year look-back period and, as a result, incentives in fee cases favor settlement. See John C. Coates IV, The Downside of Judicial Restraint: The (Non-) Effect of Jones v. Harris, 6 DUKE J. CONST. L. \& PUB. POL'Y 58, 59-60 (2010) (suggesting that shareholders do recover through settlements although their lawyers are the primary beneficiaries). A typical settlement in a fee case would involve a slight reduction in fees for a limited time period, a procedure known as "prospective relief." Plaintiffs' attorneys receive a percentage of the total fee savings and respondents avoid an unfavorable fee precedent. I estimate that on an annual basis investment management firms overcharge mutual fund customers by about $\$ 35$ billion per year. Brown, supra note 15 , at 400 . Thus, the neutering of the SEC with respect to advisory fees has had serious monetary consequences for the investing public.

76. Dozens of law review articles published on the 1970 Amendment to ICA universally fail to mention what is plainly obvious in the Senate Report: the Amendment was biased in favor of the investment management industry and politics played a major part in the legislation. It seems as though there is a major blind spot in the legal literature when it comes to the role of politics and influence in the legislative process. 
increase in costs and concomitant decrease in profits will yield increased sales and profits in the future.

The mutual fund industry is different. In what might be the all-time regulatory coup, the industry induced regulators to approve a fee on existing shareholders in order to pay marketing costs to attract new shareholders. A decent analogy would be banking regulators allowing banks to impose a fee increase on the balances of checking account customers to attract new customers with the promise of reduced fees in the future. Of course, the lower fees never materialize.

In the normal course of business, if a fund sponsor wants to increase revenues from advising a mutual fund, it will expend money on marketing to increase the fund's asset base. Fund marketing costs are often called distribution costs. Increased fund assets will increase sponsor revenues because advisory fee revenue is a (typically) fixed percentage of assets. However, if the fund sponsor industry has influence with regulators, it could persuade them to permit the imposition of a fee on existing customers to achieve an increase in assets. That is exactly what happened in 1980 when the SEC passed Rule 12b-1, which permitted fund sponsors to tap fund assets to pay for distribution costs. ${ }^{77}$ Existing customers received no material benefit from the fees, but fund sponsors profited handsomely. The SEC faced two choices: it could allow the industry to fund distribution costs out of profits, or it could impose an asset-based fee on fund investors. The industry favored the latter approach and that is what the SEC chose to do. Although the SEC's reasoning is murky, common sense and financial analysis recommend the former. The alternatives may be clarified with a simple, if somewhat stylized, example.

Assume that there is a money market mutual fund with current assets of $\$ 2$ billion and an annual advisory fee of fifty basis points $(0.5 \%)$. Assume that the economy is in a period of high interest rates, not unlike that of the 1970's and that the fund has a gross yield (prior to fees) of $10 \%$. Also assume that the fund sponsor realizes a $70 \%$ profit margin ((Revenues - Costs)/Revenues $)^{78}$ on the fees received for managing the fund. Finally,

77. Bearing of Distribution Expenses by Mutual Funds, 45 Fed. Reg. 73,898, 73,898 (Nov. 7, 1980) (to be codified at 17 C.F.R. pt. 270.12b-1).

78. Margins at that level are typical of money market funds then and now. The money fund in Gartenberg, the seminal advisory fee case, has a gross profit margin of $96 \%$. Gartenberg, 694 F.2d at 930-31. In Schuyt v. Rowe Price Prime Reserve Fund, Inc., 663 F. Supp. 962, 989 n.77 (S.D.N.Y 1987), the U.S. District Court for the Southern District of New York established the fiduciary standard maximum operating profit margin for fee cases at around $77 \%$, stating the following:

The Court wishes to make clear that it is not holding that a profit margin of up to $77.3 \%$ can never be excessive. In fact, under other circumstances, such a profit margin could very well be excessive. For example, if advisory services 
assume that an individual investor in the fund currently has an account with $\$ 100,000$ invested in the fund.

Table 1 highlights the financial differences between two alternatives: paying marketing and distribution costs out of fund sponsor profits or paying them with a levy on fund assets. Period 1 (Column A) is the base case and shows the fund sponsor with profits of $\$ 7$ million, which represents a profit margin of $70 \%$ on revenues of $\$ 10$ million (half a percent of $\$ 2$ billion). Period 2 (Columns B and C) shows the results under each alternative. It is assumed that marketing costs of $\$ 5$ million $^{79}$ are expended in Period 2 and that this results in a doubling of fund assets to $\$ 4$ billion. The Top Panel shows results for the fund sponsor and the bottom panel for the individual investor.

The principal insight from this analysis is that if the sponsor pays for marketing costs out of advisory revenues, its profits will suffer in the short run but will benefit in the future from the increased asset base. The investor is no better or worse off under this scenario. If marketing costs are charged to fund assets, the sponsor is unequivocally better off because he or she sustains profit margins on a much higher asset base. The investor is unequivocally worse off because he or she suffers from a decrease in returns with no benefits. Finally, it is useful to note that under Scenario B, the accounting is appropriate; the sponsor bears the costs and also reaps the benefits of the expenditures for marketing. Fund Investors are held harmless.

being challenged were not of the highest quality and if the directors were not so obviously qualified, fully informed, and conscientious, a similar fee structure could violate section 36(b). This Court is simply holding that on the facts presented here, the fee schedules at issue represent charges within the range of what would have been negotiated at arms-length in the light of all of the surrounding circumstances.

The consulting firm, Mutual Fund Governance Consulting, publishes summary profit margin numbers. In 2008, operating margins on money funds averaged about $70 \%$. C. Meyrick Payne \& Sara Yerkey, Profitability Benchmarks in Contract Renewal-April 2008, Mutual Fund Governance Consulting (Jan. 19, 2017, 2:30 PM), http://production.mfgovern.com/content/view/71/91 [https://perma.cc/3TSQ-XZBR].

79. Five million dollars is the equivalent of a twenty-five basis points fee against initial fund assets, the typical distribution fee imposed. This is for illustration purposes only. An actual fund sponsor would make a business judgment and gauge the trade-off between the initial hit on short-term profits and the probable long-term gain from an increased asset base. 
TABLE 1

\begin{tabular}{|c|c|c|c|c|}
\hline Column & & A & B & $\mathrm{C}$ \\
\hline \multirow[t]{2}{*}{ Period } & & 1 & 2 & 2 \\
\hline & & Initial Position & $\begin{array}{l}\text { Sponsor Pays } \\
\text { Distribution Costs }\end{array}$ & $\begin{array}{l}\text { Investor Pays } \\
\text { Distribution } \\
\text { Costs }\end{array}$ \\
\hline \multicolumn{5}{|c|}{$\begin{array}{l}\text { Results for Fund } \\
\text { Sponsor }\end{array}$} \\
\hline Assets & & $2,000,000,000$ & $4,000,000,000$ & $4,000,000,000$ \\
\hline Revenues & & $10,000,000$ & $20,000,000$ & $20,000,000$ \\
\hline \multicolumn{5}{|l|}{ Costs } \\
\hline & $\begin{array}{l}\text { Operating } \\
\text { Costs }\end{array}$ & $3,000,000$ & $6,000,000$ & $6,000,000$ \\
\hline & $\begin{array}{l}\text { Distribution } \\
\text { Costs }\end{array}$ & & $5,000,000$ & \\
\hline $\begin{array}{l}\text { Total } \\
\text { Costs }\end{array}$ & & $3,000,000$ & $11,000,000$ & $6,000,000$ \\
\hline \multicolumn{2}{|c|}{ Operating Profits } & $7,000,000$ & $9,000,000$ & $14,000,000$ \\
\hline \multicolumn{2}{|c|}{$\begin{array}{l}\text { Operating Profit } \\
\text { Margin }\end{array}$} & $70 \%$ & $45 \%$ & $70 \%$ \\
\hline
\end{tabular}

\begin{tabular}{|l|r|r|rr|}
\hline $\begin{array}{l}\text { Results for Fund } \\
\text { Investor }\end{array}$ & & & \\
\hline Funds Invested & 100,000 & 100,000 & 100,000 \\
\hline $\begin{array}{l}\text { Gross Earnings @ } \\
\mathbf{1 0 \%}\end{array}$ & & 10,000 & 10,000 \\
\hline $\begin{array}{l}\text { Less } \\
\text { Fees }\end{array}$ & $\begin{array}{l}\text { Advisory } \\
\text { Fee }\end{array}$ & & 500 & 500 \\
\hline & $\begin{array}{l}\text { Distribution } \\
\text { Fee }\end{array}$ & & 0 & 250 \\
\hline & & 500 & 750 \\
\hline \multicolumn{2}{|l|}{$\begin{array}{l}\text { Total Fees } \\
\text { Net Earnings After } \\
\text { Fees }\end{array}$} & & 9,500 & 9,250 \\
\hline \begin{tabular}{l} 
Net Return After Fees \\
\hline
\end{tabular}
\end{tabular}


It is useful to examine the genesis of Rule $12 \mathrm{~b}-1 .^{80}$

In the 1970's, the mutual fund industry was experiencing net redemptions and asked the SEC for help. At that time, front load fees were the primary method of marketing mutual funds. Here are the recollections of Alan Mostoff, director of the Division of Investment Management at the time:

And then I remember the distribution hearings that concluded in the middle ' $70 \mathrm{~s}$, participating in a meeting with the former chairman of the SEC, Hamer Budge, who was at the time the chairman of the IDS Mutual Funds where he was seeking compassion from the Commission because the funds were in net redemption and he argued that something needed to be done to help funds with distribution. I remember after the Commission meeting speaking with Irving Pollack, who was then a Commissioner. He said, "You know, we've got to do something here." And I said, "You're right." And we started on the path that ultimately led to the adoption of Rule 12 (b)-1 in $1981 .^{81}$

The revolving door at the highest levels is on full display; the IDS Chairman and former SEC Commissioner was not arguing for help for individual investors. The industry was asking the regulators for help for the industry. With Rule 12b-1, the SEC helped the industry to the clear detriment of individual investors. ${ }^{82}$

The SEC commissioned a study ${ }^{83}$ that eventually led to the imposition of marketing (distribution) fees on fund assets. For reasons that are not

80. See, e.g., John P. Freeman, The Use of Mutual Fund Assets to Pay Marketing Costs, 9 LOY. U. CHI. L.J. 533, 543-48 (1978) (describing both sides of the debate between the SEC and the fund industry concerning whether mutual fund assets could be used as a source of payment for marketing costs); The Roundtable on Investment Company Regulation, SEC. \& EXCH. COMM'N Historical SOC'Y (Dec. 4, 2002), http://www.sechistorical.org/collection/programs/INV1204Transcript.pdf [https://perma.cc/VTY6-ZPKX] [hereinafter Roundtable].

81. Interview by Richard Rowe with Allan Mostoff, Gen. Counsel, Dechert LLP, in D.C. (Oct. 30, 2002), http://3197d6d14b5f19f2f440-5e13d29c4c016cf96cbbfd197c579b45. r81.cf1.rackcdn.com/collection/oral-histories/mostoff100202Transcript.pdf [https://perma.cc/L6DR-XHFG].

82. Where distribution fees are concerned, the distinction between broad and narrow capture is blurred. SEC Commissioners are political appointees and subject to political pressures. SEC staff responded to pressure from above with no obvious venal motivation on their part. So, the Commission was apparently captured, but staff integrity was not compromised. Industry influence was clearly at work, but was it broad or narrow capture?

83. See Div. of Inv. Mgmt. Reg., U.S. Sec. \& Exch. Comm'n, Mutual Fund Distribution AND SECTION 22(D) OF THE INVESTMENT COMPANY ACT OF 1940 19, 20 (1974) (noting that "net redemption status has lately replaced the sales records the industry earlier enjoyed" and how fund distribution "seems to have become even less profitable ...."). 
entirely clear, during the rulemaking process, the SEC conflated "advisor profits" and "fund assets." Freeman tells us that:

Drawing on written submissions and testimony from industry participants, the SEC staff reached various conclusions. Those findings are worth noting because they affirm the SEC staff's understanding that the sales push was linked to compensation and its appreciation that fund assets (under the euphemism of "advisory profits") were already being used to pay for distribution in the fund industry. ${ }^{84}$

84. Freeman, supra note 38, at 753. Note how "advisor profits" are viewed by the SEC staff as a "euphemism" for fund assets. This is inaccurate because, consistent with the implications of Table 1, if marketing costs come directly from fund assets, they do not reduce advisor profits. The genesis of the confusion appears to be the uncritical acceptance (intentional or otherwise) of somewhat ambiguous (intentional or otherwise) statements by John Bogle, founder of the Vanguard Group of mutual funds, a no-load complex:

[W] e want to reemphasize that in the conventional mutual fund complex today, the aggregate management or advisory fees generated by the funds as a group provide substantially all of the resources expended for the distribution of each fund in the group. In the case of no-load funds, all of the resources allocated to distribution are provided by these fees, since no other revenues are generated. In the case of funds with sales commissions, most of the distribution costs are financed by such management fees, since the sales concession revenues retained by the adviser are almost always wholly inadequate to cover these costs. Therefore, the proposed Vanguard arrangements for the joint sharing of distribution costs do not depart from present industry practice. They merely make explicit (with the commensurate benefits of full disclosure) what is already implicit in the financing of mutual fund distribution on an industry-wide basis.

The simple fact of the matter is that mutual fund shareholders are the sole source of financing all mutual fund activities - whether administration, advisory, or distribution.

Freeman, supra note 80, at 536-37 n.18 (quoting John C. Bogle, Proposed Statement on the Vanguard Distribution Application at the Securities and Exchange Commission Hearing 32 (Jan. 5, 1978)) (last emphasis added). Freeman then adds: "The Proposed Vanguard Statement indicates that assets of the Vanguard complex of funds have been used, and are being used, to pay marketing costs of over $\$ 1$ million annually." Id. This appears to be an inaccurate statement because paying for distribution costs out of advisory fees is not equivalent to paying them directly out of assets. There are three things to note about Bogle's statement: 1) Prior to $12 \mathrm{~b}-1$, all distribution costs were paid out of aggregate advisory fees. This is consistent with the implications of Table 1;2) Bogle never explicitly stated that fund assets were used directly for distribution; 3) It is a true statement that ultimately "shareholders are the sole source of financing all mutual fund activities." However, it is true only insofar as shareholders pay for distribution costs indirectly by paying for advisory services and fund sponsors (appropriately) use advisory revenues to pay for marketing. Sponsor profits are therefore reduced by such expenditures. It appears as though Bogle's statements contain a studied ambiguity designed to allow the SEC to rationalize paying for distribution costs out of fund assets, the ultimate aim of the industry. 
Prior to 1980 and the passage of Rule 12b-1 the use of advisor profits was the only means available for no-load funds to market their funds. Thus, there was implied if not explicit regulatory approval for the procedure. However, it is clear from Table 1 above that paying for distribution costs from fund sponsor profits is very different from paying them directly from fund assets. Problems arose when the possibility of explicitly paying for distribution from fund profits occurred. Freeman reveals how the SEC granted a no-action letter to Mutual Liquid Assets, which wanted to explicitly

"reallocate" one-half of the advisory fee (.25 percent) to dealers selling the fund. . . . In essence, the Mutual Liquid Assets noaction request presented an opportunity to move the practice of using fund assets for marketing costs out of the closet. The staff's response indicated that if the management of Mutual Liquid Assets had nerve enough to fully and fairly disclose what they planned to do with fund shareholders' money, then the Division of Investment Management had nerve enough to let them. ${ }^{85}$

Note again the conflation of advisory fees with fund "shareholder's money" (assets). If the SEC confused fund assets with advisor profits, the industry and the ICI did not. In response to the Mutual Liquid Assets noaction letter:

In a letter on a "matter of extreme urgency" that was hand-carried to the SEC, the Investment Company Institute's senior vice president and general counsel complained that the staff had made "apparent changes in the ground rules" dealing with payment for fund marketing costs in the absence of a public expression by the Commission through promulgation of a rule or a release. ${ }^{86}$

Later, the SEC instructed staff to withdraw the Mutual Liquid Assets no-action letter. ${ }^{87}$ In 1978, the SEC issued an Advance Notice of Proposed Rulemaking regarding the conditions under which it might permit funds to use assets to finance distribution expenses. ${ }^{88}$ The SEC received more than fifty comments on this proposal and thirty of the comments, including twenty from individual investors, opposed the proposal. ${ }^{89}$ Thus, the SEC imposed Rule 12b-1 over the united disapproval of the individual investors

85. Freeman, supra note 80 , at 541.

86. Id. at 541-42.

87. Id. at 542

88. Advance Notice of Proposed Rulemaking on the Bearing of Distribution Expenses by Mutual Funds, 43 Fed. Reg. 23,589 (May 23, 1978).

89. Bearing of Distribution Expenses by Mutual Funds, 44 Fed. Reg. 54,014, 54,015 (proposed Sept. 17, 1979). 
who weighed in on the issue. Essentially, the SEC capitulated to the fund industry.

It is useful to note that prior to the imposition of Rule $12 \mathrm{~b}-1$, under Section 12(b) of the ICA, investment managers were forbidden to utilize fund assets for distribution purposes. ${ }^{90}$ The reason for the prohibition was the concern that if "a fund grows in size only by heightened marketing or other distribution efforts, and the fund itself pays for such efforts, the adviser stands to reap greater compensation for reasons divorced from the fund's investment performance." 91 Consistent with this concern, the SEC initially proposed that fund advisers, rather than continuing to be paid management fees based on the size of their funds, might be required to agree to a fixed dollar payment. ${ }^{92}$ The SEC also proposed protecting existing shareholders who had already absorbed the distribution expenses attendant to their purchases:

Accordingly, the SEC proposed that these shareholders be "grandfathered," protected against indirectly bearing, in any part, payments out of fund assets to sell new shares to investors[.] . . . However, these two conditions - flat management fees for advisers and grandfathering of existing shareholders - were dropped in the face of fund industry opposition. ${ }^{93}$

The industry argued that there would be prospective benefits to investors because as asset levels increased in the future, economies of scale would allow for a decrease in fees. ${ }^{94}$ This assertion was apparently met with some skepticism from the SEC. Rule $12 \mathrm{~b}-1$ as implemented required fund directors to annually review the plan and "conclude, in the exercise of reasonable business judgment and in light of their fiduciary duties under state law and section 36 of the Act, that there is a reasonable likelihood that the [12b-1] plan will benefit the fund and its shareholders." 95

Of course, the prospective financial benefits to investors never materialized. An SEC staff study in 2000 found "that, everything else equal, funds with $12 \mathrm{~b}-1$ fees had total expenses that were higher than those of other funds, but by an amount that was slightly less than the maximum 12b-I fee." ${ }^{96}$ Essentially, what this says is that expense ratios rose by an

90. Eric D. Roiter, Disentangling Mutual Fund Governance from Corporate Governance, 6 HARV. BuS. L. REV. 1, 35 (2016).

91. Id.

92. Id. at 38 .

93. Id. at 39 .

94. Freeman, supra note 80 , at 543-55.

95. Payment of Asset-Based Sales Loads by Registered Open-End Management Investment Companies, 53 Fed. Reg. 23,258, 23,275 (June 21, 1988) (to be codified at 17 C.F.R. pts. 239, 270, and 274).

96. Div. of Inv. Mgmt., U.S. SeC. \& Exch. Comm'n, Report on Mutual Fund Fees 
amount approximately equal to distribution fees. Similarly, SEC-employed economist Dr. Lori Walsh carefully examined the evidence on distribution fees and found:

[W] hile funds with 12b-1 plans do, in fact, grow faster than funds without them, shareholders are not obtaining benefits in the form of lower average expenses or lower flow volatility. Fund shareholders are paying the costs to grow the fund, while the fund adviser is the primary beneficiary of the fund's growth. ${ }^{97}$

Thus, available evidence confirms the essential insights from Table 1. Fund sponsors profit handsomely from offloading distribution costs on the public and the public receives little or no financial benefit.

The industry was able to outmaneuver the SEC once distribution fees were allowed. The small, twenty-five basis point fee envisioned by the SEC in 1980 soon morphed into the hundred basis point fees typical today. ${ }^{98}$ The incremental seventy-five basis points support Contingent Deferred Sales Charges (CDSCs). ${ }^{99}$ CDSCs are a form of sales commission where the commission is paid over time by an incremental $12 \mathrm{~b}-1$ fee added to the expense ratio. ${ }^{100}$ Research indicates that investors are less aware of and sensitive to fees buried in an expense ratio than they are to explicit sales loads. ${ }^{101}$

There has been extensive abuse of CDSCs especially as it relates to B Share or back load funds. A broker who recommends and sells B Shares realizes an immediate commission in the neighborhood of 5\%. However, the fund purchaser pays for the commission or load over time in the form of a seventy-five basis point per year increased distribution fee. As long as the fund is held for a specified period, typically seven or eight years, the investors will pay no additional fees. If sold prior to the specified period the investor will pay a fee, which is the difference between the amount paid via distribution fees and the actual commission paid to the selling broker. Hence the term "back-end load" fund. ${ }^{102}$

AND EXPENSES $\$$ III(D)(i) (2000), http://www.sec.gov/news/studies/feestudy.htm [https://perma.cc/G4DH-WE65] [hereinafter SEC Staff Study].

97. Lori Walsh, The Costs and Benefits to Fund Shareholders of 12B-1 Plans: An Examination of Fund Flows, Expenses and Returns, U.S. SEC. \& EхCH. COMM'N 2 (Apr. 30, 2004), https://www.sec.gov/rules/proposed/s70904/lwalsh042604.pdf [https://perma.cc/A4GG-K252] [hereinafter Walsh Report].

98. Freeman, supra note 38, at 777.

99. Contingent Deferred Sales Charges (CDSCs) are also referred to as Contingent Deferred Sales Loads (CDSLs).

100. Freeman, supra note 38, at 761-62.

101. Barber et al., supra note 55, at 2118 .

102. Freeman, supra note 38, at 762-67. 
The SEC never envisioned the imposition of CDSCs when it imposed Rule $12 \mathrm{~b}-1$ in 1980 . The tone of discussion of $12 \mathrm{~b}-1$ fees at the meeting of the SEC Historical Society in 2002 is revealing. One comment by Kathryn McGrath, ${ }^{103}$ Director of the SEC Division of Investment Management from 1983 to 1990 , is especially illuminating: "My biggest failure, I think, was trying to tackle and clean up Rule $12 \mathrm{~b}-1 \ldots$. There was too much money flowing through 12(b)-1 fees to make it touchable."104 It is telling that the failure to clean up $12 \mathrm{~b}-1$ fees had nothing to do with public policy or investor protection and everything to do with political clout. As Freeman has said, "The money flowing to Wall Street through 12b-1 in the 1980s is a pittance compared to the nearly $\$ 12$ billion generated annually by the rule today. If $12 \mathrm{~b}-1$ was 'untouchable' in the 1980 s, one cannot be optimistic about reform today." 105

Given the evidence that there has been no discernable diminution of overall fees resulting from Rule $12 \mathrm{~b}-1$, it is of interest to note the abject failure of mutual fund trustees and board members as it relates to distribution fees. Approximately $60 \%$ of all mutual funds impose distribution fees and in the more than thirty-five years since 1980 every mutual fund board has annually certified that: "in the exercise of reasonable business judgment and in light of their fiduciary duties under state law and under sections 36(a) and (b) ... of the Act,...there is a reasonable likelihood that the plan will benefit the company and its shareholders." 106 Given the research evidence cited above, it is clear that the whole annual exercise is a charade and that boards and trustees are captives of fund sponsors. Mutual fund investors have been systematically fleeced for thirty-five years.

Rule $12 \mathrm{~b}-1$ is still in effect today and makes less sense now than it did in 1980. Freeman, one of the original architects of distribution fees, characterizes the current distribution system as a "mess." 107 He has written: "When Rule 12b-1's supposed plusses are scrutinized closely, it becomes evident that the money management industry has outwitted and outmaneuvered the federal agency that supposedly regulates it, to investors' detriment." 108

The passage of Rule $12 \mathrm{~b}-1$ is another clear example of broad regulatory capture of the SEC. The rule was instituted to help the

103. Biography of Kathryn Bradley McGrath, U.S. SEC. \& ExCH. COMM'N, https://www.sec.gov/spotlight/rule12b-1/bio/kbmcgrath.pdf [https://perma.cc/MNN8C2RB].

104. Roundtable, supra note 80 , at 108.

105. Freeman, supra note 38 , at 788 .

106. 17 C.F.R. $\$ 270.12 b-1$ (2016).

107. Freeman, supra note 38 , at 788 .

108. Id. at 809 . 
investment management industry and, in retrospect, was contrary to the public interest. Apparently, SEC staff believed that allowing the industry to tap into fund assets was no different than allowing fund sponsors to use profits to fund distribution. The belief that fund assets and sponsor profits are equivalent was voiced by SEC alumni at the meeting of the SEC Historical Society in 2002. ${ }^{109}$ That belief apparently exists today.

In the matter of CDSCs, the industry was able to outmaneuver the SEC and the extra fees became "untouchable." ${ }^{\prime 10}$ SEC staff was naïve but probably not venal. It does not appear as though the SEC staff was "for sale." This example of broad regulatory capture of the SEC has resulted in billions of dollars per year of inappropriate fees charged against fund assets. ${ }^{111}$

\section{Soft Dollars}

The term "soft dollars" seems to carry a rather benign connotation. The reality could not be more different. David Swensen, Chief Investment Officer of Yale University, characterizes soft dollars as "the slimy underbelly of the investment world, [that] deserve a harsher name that reflects the odious nature of the kickbacks they describe."

In effect, soft dollars are like distribution fees: they involve investment managers spending shareholders' money on items such as research or other services ${ }^{113}$ that would normally reduce their profits. ${ }^{114}$ Soft dollars reduce shareholder returns and, unlike distribution fees, which are at least explicitly disclosed, they are totally opaque to shareholders.

109. Roundtable, supra note 80 , at $94-95$.

110. Freeman, supra note 38 , at 788 .

111. At the end of 2007, the year that Freeman published his article and prior to the 2008 market meltdown, open-end fund assets exclusive of money funds totaled about $\$ 8.5$ trillion. Distribution fees totaled about $\$ 13.5$ billion with approximately $60 \%$ supporting shareholder services and $40 \%$ supporting CDSCs. Since 2007, the dollar level of advisory fees has been essentially flat in spite of a new doubling of mutual fund assets. This is the result of a dramatic increase of assets invested passively as well as some investors avoiding funds with distribution fees. This information has been compiled from MoRnINGSTAR DIRECT, http://www.morningstar.com/company/direct [https://perma.cc/88TP-MLEX].

112. David F. Swensen, UnConventional Success: A Fundamental Approach to PERSONAL INVESTMENT 205 (2005).

113. Thomas P. Lemke \& Gerald T. Lins, Soft Dollars and Other Trading ACTIVITIES $§ 1: 1$ (2016).

114. Many fund sponsors disclose dollar commission costs in the annual Statement of Additional Information, a report few shareholders are even aware of. Soft dollar amounts are never reported. Funds do report trading activity in the abstract when they disclose turnover ratios. 
Most mutual funds are actively managed which means that they frequently buy and sell securities in an attempt to outperform benchmark portfolios. When securities are traded, a commission must be paid to the brokerage firm that executes the trade. Commission costs are added to the costs of security purchases and deducted from the proceeds of sales. Thus, commissions are a drag on shareholder returns. Commission costs are invisible because they are never explicitly disclosed in prospectuses or shareholder reports.

Commission costs on institutional sized trades are typically about a penny a share. When soft dollars are involved, commission costs are typically about five cents per share. ${ }^{115}$ The extra four cents per share may seem small, but it costs investors hundreds of millions of dollars per year in extra costs for which they receive no benefit. Investment management firms receive benefits in the form of "research" from brokerage firms. ${ }^{116}$ Research costs are a normal cost for investment management firms, and thus, soft dollars, like distribution fees, are a method investment managers use to get shareholders to pay some of their costs and thus subsidize their (fund sponsor) profits. ${ }^{117}$

Soft dollar arrangements, an artifact of the 1975 deregulation of brokerage commissions, are currently legal. Before May 1, 1975, the New York Stock Exchange fixed commission rates. ${ }^{118}$ Because brokerage firms were unable to compete on price (commission rates), they attracted institutional trades by bundling research reports and advice with brokerage services. ${ }^{119}$ Thus, institutional consumers of brokerage services were paying excessive commissions but the excesses were (supposedly) offset by the value of the research they received from the brokerage firms.

The SEC-mandated negotiated commission rates in 1975 would have broken the relationship between commissions and bundled research. ${ }^{120}$

115. Michael A. Goldstein et al., Brokerage Commissions and Institutional Trading Patterns, 22 REV. FIN. STUDIES 5175, 5180 (2009).

116. Fisch, supra note 64 , at 2000.

117. See Office of Compliance, Inspections \& Examinations, U.S. Sec. \& Exch. COMm'n, InsPection Report on the SOFt Dollar Practices of BroKer-Dealers, INVESTMENT ADVISERS AND MUTUAL FundS (Sept. 22, 1998), https://www.sec.gov/news/studies/softdolr.htm [https://perma.cc/NN8Z-Q9FA] (finding management firms also use funds in soft dollar arrangements for non-research items such as telephone bills, legal expenses, and administrative purpose, among other things).

118. See Gordon v. N.Y. Stock Exch., 422 U.S. 659, 662 (1975) (discussing how the practice of fixed commission rates led to, as of May 1, 1975, the elimination of fixed rates).

119. D. Bruce Johnsen, The SEC's 2006 Soft Dollar Guidance: Law and Economics, 30 CARDOZO L. ReV. 1545, 1556 (2009).

120. See Adoption of Securities Exchange Act Rule 19b-3, Exchange Act Release No. 11,203, 6 SEC Docket 147 (Jan. 23, 1975) (discussing how Rule 19b-3 prohibits any exchange from requiring its members to charge fixed commission rates after a certain date 
However, the brokerage and money management industries convinced the U.S. Congress to intervene. Congress carved out a safe harbor exemption by enacting Section $28(\mathrm{e})^{121}$ of the Securities Exchange Act of 1934. Under the exemption, brokerage firms could legally charge above-market commission rates by bundling "research" with commissions. ${ }^{122}$ It bears repeating that research costs are actually an expense of the money manager and should be charged against its profits. By charging above-market commission rates, fund shareholders effectively subsidize advisor profits.

The soft dollar carve-out did not occur in a vacuum. It occurred because brokerage and money management special interests were able to persuade Congress to help them at the expense of the investing public, a clear manifestation of broad regulatory capture. Absent the carve-out for soft dollars, the SEC would not have allowed fund companies to pay excessive commissions at the expense of fund investors.

Initially, the SEC interpreted the soft dollar carve-out narrowly. They ruled that the safe harbor does not apply to research products that are "readily and customarily available... to the general public on a commercial basis." 123 This narrow interpretation was consistent with the SEC's protection of investors within the confines of the loophole that Congress created. Eventually, as an apparent result of narrow capture, the SEC loosened this strict interpretation of what constituted research. This process will be examined in the next section.

\section{NARrow Regulatory CAPTURE - FEE Disclosure, DISTRIBUTION FEES, SOFT DOLLAR COMMISSIONS, AND TRADING COSTS.}

The SEC bills itself as the investors' advocate. ${ }^{124}$ The evidence suggests otherwise. The SEC Division of Investment Management has been at best passive in the face of industry misinformation and at worst complicit with the mutual fund industry in blocking needed reforms.

The effective narrow capture of the SEC is largely a recent occurrence that has arisen in the context of increased pressure from the U.S. Congress and other sources to act contrary to industry interests and in the public

or authorize members to "arrange for the charging of fixed rates of commission").

121. Securities Acts Amendments of 1975, Pub. L. No. 94-29, § 21, 89 Stat. 97, 161 (1975) (codified as amended at 15 U.S.C. 78bb (2012)).

122. Id.

123. Fiduciary Money Managers: Use of Commission Payments by Fiduciaries, Exchange Act Release No. 12,251, 41 Fed. Reg. 13,678, 13,679 (Mar. 31, 1976).

124. Mary L. Schapiro, Chairman, U.S. Sec. \& Exch. Comm'n, Address to the Council of Institutional Investors (Apr. 6, 2009), https://www.sec.gov/news/speech/2009/ spch040609mls.htm [https://perma.cc/5ZRM-WJ9W]. 
interest. The genesis of the reform pressures was the mutual fund scandals that came to light in 2003.

Unfortunately, the benign involvement of the U.S. Congress was unsuccessful because of industry intervention and the industry remains essentially unreformed.

In October 2003, New York Attorney General Eliot Spitzer criticized the SEC for not detecting mutual fund industry wrongdoing. "This has been an outrageous betrayal of the public trust by that agency,' he said in an interview. 'The regulators who were supposed to have been watching this industry were asleep at the switch. And I'm going to pull that switch."" 125 The wrongdoings that Mr. Spitzer identified focused on the practices of late trading and market timing, although he was also concerned about corporate governance of mutual funds and the overcharging of mutual fund customers relative to institutional clients.

The essence of wrongdoing in the late trading and market timing schemes is that investment managers assisted large investors like hedge funds in skimming gains that belong to long-term customers, typically small investors. Late trading enables some customers to trade mutual funds at Net Assets Value (NAV) prices after the 4 PM deadline for order entry. ${ }^{126}$ If significant news hits after 4 PM and a hedge fund can trade at 4 PM prices, the hedge fund has effectively arbitraged the mutual fund. The improper short term trading dilutes long-term investor gains. It has been estimated that late trading in international funds cost long term shareholders an annual average of 3.8 basis points. ${ }^{127}$ The corresponding cost for domestic equity funds was 0.9 basis points from 1998 to $2003 .{ }^{128} \mathrm{It}$ was estimated that the cost to long-term mutual fund investors was in the neighborhood of $\$ 400$ million per year. ${ }^{129}$

Market timing is similar in result although more complicated in explanation. It involves arbitrage of mutual fund NAV's using stale prices, typically for funds that own foreign securities. International stocks trade in different time zones. Some of these stocks may not have traded for as

125. Tom Lauricella et al., Mutual Funds Face Overhaul As Spitzer and SEC Fight for Turf, WALl ST. J., Oct. 31, 2003, at A1.

126. Id. See also Fast Answers: Late Trading, U.S. SEC. \& ExCH. Comm'N, https://www.sec.gov/answers/latetrading.htm [https://perma.cc/LJB4-BX3A] (last visited Jan. 13, 2017) (defining "Late Trading" as "the practice of placing orders to buy or redeem mutual fund shares after the time as of which a mutual fund has calculated its net asset value (NAV), usually as of the close of trading at 4:00 p.m. Eastern Time, but receiving the price based on the prior NAV already determined as of that day.").

127. Eric Zitzewitz, How Widespread Was Late Trading in Mutual Funds?, Am. Econ. REV. 284, 284 (2006).

128. Id.

129. Id. 
much as fifteen hours ahead of the 4 PM valuation points in the U.S. If U.S. or other markets have risen since the closing of the foreign market, it is a safe bet that the foreign market will move in the same direction when it opens again. It has been estimated that trading in stale prices permited arbitrageurs to earn excess returns between $35 \%$ and $70 \%$ per year trading in international funds. The costs of market timing to mutual fund shareholders approximated $\$ 5$ billion per year. ${ }^{130}$

It turns out that the SEC was not totally asleep at the switch where market timing was concerned. In April 2001, the SEC sent a letter to the ICI advising mutual funds that when significant events occur a fund must value the portfolio pursuant to a "fair value pricing methodology.", The procedure would have effectively eliminated stale price arbitrage but was essentially ignored by the industry. Columbia Law Professor John C. Coffee, Jr. had some interesting and nuanced insights into this clear example of regulatory capture:

[T] he ICI mounted a political campaign and issued an elaborate white paper in 2002, defending the right of a fund in good faith to rely on the closing market price in the foreign market and resisting any obligation to predict future value. Joining the fray on the side of their clients, the committee on mutual fund law of the Association of the Bar of the City of New York, which is prominent in the securities law field, warned the SEC's staff that it had no "basis to contest the good faith of directors in making fair value determinations." Members of Congress also wrote critical letters to the SEC.... In consequence, the SEC staff in late 2001 appears to have backed away from its earlier insistence on fair valuing, not abandoning its policy on a formal level but lowering the profile of its position and ceasing to interpret it in ways that constrained fund managers. ... Deep down, what is at work here is less a formal policy of accommodation than the habitual response of overworked bureaucrats operating in an esoteric and insular field of law that the public does not understand and that is dominated by a powerful lobby playing the role of the 600-pound gorilla. Add to this mix a rapidly revolving door between the SEC and private legal practice, and SEC staffers tend to learn that, unless an issue has become high profile, it is best not to rock the boat. Efforts to expand the law only gain a staffer the reputation of a troublesome dissident and

130. Eric Zitzewitz, Who Cares About Shareholders? Arbitrage-Proofing Mutual Funds, 19 J.L., ECON. \& ORG. 245, 246 (2003).

131. Letter from Douglas Scheidt, Assoc. Dir. \& Chief Counsel, U.S. Sec. \& Exch. Comm'n, Div. Inv. Mgmt., to Craig S. Tyle, Gen. Counsel, Inv. Co. Inst. (Apr. 30, 2001), http://www.sec.gov/divisions/investment/guidance/tyle043001.htm [https://perma.cc/6NXP5QLR]. 
interfere with his ability to return to private practice with an enhanced resume. ${ }^{132}$

Once Mr. Spitzer publicly revealed the industry's wrongdoing, the SEC quickly responded to the late trading and market timing loopholes. ${ }^{133}$ The U.S. Congress, now alerted to problems in the mutual fund industry far beyond the narrow confines of late trading and market timing, proposed legislation that would, among other things, eliminate distribution fees and soft dollars and significantly enhance disclosure of advisory and trading costs. $^{134}$ This presented the SEC with a very visible and needed blueprint of reform in the industry. As the next section demonstrates, the SEC was able to mitigate or avoid imposing new and necessary regulation of the industry and the industry was able to largely blunt the proposed legislation. In short, the industry was able to maintain the status quo because it had successfully captured the SEC.

\section{A. Fee Disclosure - Undisclosed Dollar Expenses}

The primary means by which the SEC fulfills its mission to protect investors and assure they are well-served is through requiring the full disclosure of relevant information. The issue of appropriate disclosure as it relates to mutual funds is especially important given the large and increasing numbers of inexperienced investors who are forced to make important decisions about mutual funds in retirement accounts. A previous section documented the academic evidence that most mutual fund investors are naïve or lack fundamental knowledge of the financial environment or both. ${ }^{135}$ This view is supported by former SEC Commissioner Arthur Levitt, who wrote subsequent to his tenure at the SEC:

I think fund companies believe that the underinformed investor is a more profitable investor. Barry Barbash, who as head of the SEC's Division of Investment Management oversaw the mutual fund industry, told me in 1993 that he had no idea how much investors really understood about mutual funds. So we hired a polling firm to find out. After several surveys and even a few

132. John C. Coffee, Jr., A Course of Inaction: Where was the SEC when the Mutual Fund Scandal Happened?, LEGAL AfFAIRS 48-49 (Mar.-Apr. 2004), http://www.legalaffairs.org/issues/March-April-2004/review_coffee_marapr04.msp [https://perma.cc/K78B-AXTC].

133. Press Release, U.S. Sec. \& Exch. Comm'n, SEC Takes Steps to Address Late Trading, Market Timing and Related Abuses, https://www.sec.gov/news/press/2003168.htm [https://perma.cc/WB2Z-ADW2].

134. Mutual Fund Reform Act of 2004, S. 2059, 108th Cong. $\S \S 310-317$ (2004).

135. See Lusardi, supra note 42 , at 261 (demonstrating the poor results from a study based on survey questions formulated to measure a general understanding of finance). 
focus groups-efforts the Investment Company Institute, the industry's trade group, derided as pseudo-scientific - we realized that most investors were even more befuddled than we had imagined. ${ }^{136}$

Chairman Levitt is not alone in his post-retirement view that the industry seeks to keep mutual fund investors "underinformed." Other authors have also charged the SEC with being overly solicitous of industry views and ignoring the academic research on mutual fund literacy of investors:

By advancing the notion of a functioning, investor-driven market, the ICI discourages intrusive regulation of the industry. The ICI has masterfully played the role of supporting disclosuresimplification reforms in the name of investor empowerment, while resisting providing clear, comparative information regarding fund costs on the grounds that investors can glean such information on their own.

The SEC has undertaken only marginal reforms, primarily focused on streamlined disclosure and formulaic warnings. Relying significantly on the industry for information about investor needs, the SEC has largely accepted the story of a wellfunctioning market. While the SEC's reforms play around the edges of addressing investors' inability to fend for themselves, the agency seems in denial about the extent of this problem. The SEC's almost complete disregard of academic studies of fund investor behavior ensures that investors' limitations will continue to be greatly underestimated, and that any further reforms will miss their mark. ${ }^{137}$

Dollar mutual fund fees are essentially invisible. Fees are automatically deducted from a fund's assets. Investors never see an invoice and never have to write a check. Moreover, investors never know what actual dollar expenses are being subtracted from their investment balances. ${ }^{138}$ Yet fees can have a dramatic impact on fund returns when compounded over time. The disclosure of annual dollar expenses on an investor's mutual fund or brokerage statement would be an unequivocal

136. Arthur levitt, Take on the Street: What Wall Street and Corporate America Don't Want You to Know, What You CAN Do to Fight Back 43 (2002).

137. Alan R. Palmiter \& Ahmed E. Taha, Mutual Fund Investors: Divergent Profiles, 2008 Colum. Bus. L. REV. 934, 1018-19 (2008).

138. U.S. Gen. Accounting Office, GAO-00-126, Mutual Fund FeEs: Additional Disclosure COUld Encourage Price Competition 7 (2000), http://www.gao.gov/assets/160/156959.pdf [https://perma.cc/3HSP-NPQ9] (showing that investors do not see specific "in dollar amounts" that were deducted from their funds on account statements). 
plus for investors. There is no plausible reason that investors should not know exactly and explicitly what expenses they are paying.

In 2001, the U.S. General Accounting Office, in conjunction with a study of mutual funds, recommended that "the Chairman of the Securities and Exchange Commission (SEC) require that the quarterly account statements that mutual fund investors receive include information on the specific dollar amount of each investors' share of the operating expenses that were deducted from the value of the shares they own." 139 The Mutual Fund Reform Act of $2004^{140}$ also recommended that the SEC require that fund managers display dollar expenses on quarterly account statements.

The industry pushed back against these recommendations. The ICI commissioned a survey of the mutual fund industry. ${ }^{141}$ The main argument against the proposal was the incremental costs involved, which were found to be in the neighborhood of $\$ 65$ million annually after an initial one-time cost of about $\$ 200$ million. The ICI argued that these costs were a prohibitive burden on an industry with annual revenues above $\$ 100$ billion and where profit margins in the range of $50 \%$ to $60 \%$ are the norm. ${ }^{142}$ The $\$ 65$ million of annual costs represents about 0.065 of $1 \%$ of annual industry revenues and a small fraction of the approximately $\$ 12$ billion of annual distribution fees paid by investors.

The SEC chose not to follow the recommendations of the GAO or the Mutual Fund Reform Act, opting instead for a procedure that would require the investor to calculate an estimate of his annual dollar costs. ${ }^{143}$

We acknowledge that individualized expense disclosure in quarterly account statements would have the benefit of providing cost disclosure tailored to each investor. Our approach, however, effectively permits an investor to estimate this personalized information readily (by dividing the investor's account value by $\$ 1,000$ and multiplying the result by the cost shown for a $\$ 1,000$ investment).... One commenter estimated, based on a survey of various industry participants conducted in 2000, that the aggregate costs to survey respondents associated with calculating and disclosing individualized fund expenses would be $\$ 200.4$

139. Id. at 1 .

140. Mutual Fund Reform Act of 2004, S. 2059, 108th Cong. § 210 (2004). After extensive hearings and testimony, S. 2059 died in the Senate Banking Committee. See infra note 212 and accompanying text (describing the details surrounding the death of the bill).

141. ICI Survey on GAO Report on Mutual Fund Fees, INV. Co. InST., (Jan. 31, 2001), https://www.ici.org/pdf/03_sec_shreport_appa.pdf [https://perma.cc/L8HP-Z9Z9].

142. Id. at 2 .

143. Shareholder Reports and Quarterly Portfolio Disclosure of Registered Management Investment Companies, Securities Act Release No. 8393, Exchange Act Release No. 49,333, Investment Company Act Release No. 26372, 69 Fed. Reg. 11,244, 11,247 (Mar. 9, 2004). 
million in initial implementation costs and \$65 million in annual, ongoing costs (footnote omitted). By contrast, we estimate that the costs for standardized cost disclosure in shareholder reports, including printing and mailing costs, and the costs of preparing the new disclosure, would total approximately $\$ 16$ million annually. ${ }^{144}$

The SEC rationale is highly disingenuous. The most important impact of the disclosure of actual fees would be to increase investor awareness, which the SEC approach fails to do. Moreover, given the documented lack of financial literacy of the investing public, it is highly doubtful how "readily" the typical individual investor could estimate this personalized information. However, the procedure is clearly inferior to a personalized disclosure. The decision was ostensibly made on the basis of incremental costs to the industry and not the interest of investors. Costs aside, the industry avoided having to explicitly reveal dollar costs to investors because they were able to persuade the SEC to support their position. As Arthur Levitt has said, "[t]o the industry, one of the greatest design features of funds is the way they artfully camouflage fees as a percentage of assets." 145

\section{B. Distribution Fees}

Rule 12b-1 was adopted by the SEC in 1980 and was problematic from the start. The cost savings promised by the industry never materialized and the fees morphed into uses not contemplated by the SEC when the rule was promulgated. The use of $12 \mathrm{~b}-1$ fees to support CDSCs enabled (and still enables) the industry to effectively camouflage sales commissions by burying them in the expense ratio, where the use of the funds is disguised.

The SEC has faced increasing pressure to reform on eliminate $12 \mathrm{~b}-1$ fees. The evidence that distribution fees are essentially deadweight costs exposed by the SEC ${ }^{146}$ and Walsh studies ${ }^{147}$ highlighted problems with the program. Then, after extensive hearings, the Mutual Fund Reform Act (MFRA) of $2004^{148}$ recommended the elimination of distribution fees. The testimony of the bill's primary architect, Senator Peter Fitzgerald, is insightful and instructive:

144. Id

145. LEVITT, supra note 136, at 47.

146. SEC Staff Study, supra note 96.

147. See Walsh Report, supra note 97 (showing the intended benefit of distribution fees does not actually exist).

148. Mutual Fund Reform Act of 2004, S. 2059, 108th Cong. (2004). 
Free market principles would typically discipline excessive distribution costs as a direct bite out of profits - but fund advisers are (1) collecting their substantial fees as a percentage of fund assets; and (b) financing the sustained swelling of those very same assets with investors' money. Put another way, the King compels the cook to buy the food that fattens the King. Does the King worry about his food budget? Unlikely. MFRA rearranges this incentive structure - without dictating any specific diet. Fund advisers will now bear distribution expenses - and if, as appears virtually self-evident, some of these expenses are excessive, we can be certain that fund advisers, spending their own money, will discover the cost discipline that has been elusive to date.

Only Congress can rationalize the fund distribution system that its own Act of 64 years ago created - and that the SEC complicated with its well-intended but injuriously-perpetuated Rule $12 \mathrm{~b}-1 .{ }^{149}$

The encyclopedic article on distribution fees by Professor John Freeman examined the issues in great detail. ${ }^{150}$ A principal problem with distribution fees revolves around "Spread Loads" or "Contingent Deferred Sales Charges" (CDSCs). A threshold issue is the problematic use of the term "contingent" in describing the fees in " $\mathrm{B}$ " shares or back load share classes. In fact, there is nothing contingent about the fee. ${ }^{151}$ The broker is paid the sales fee immediately and the (typically) seventy-five basis point $12 \mathrm{~b}-1$ fee is used to amortize a loan that funds the payment. ${ }^{152}$ The only contingency is that if the fund is sold prior to the total amortization of the loan, the investor must then pay the balance of the loan. This procedure gives rise to several problems, first among which is the potential deception involved with the use of the term "contingent." A selling broker may truthfully say to the customer that "if you buy "B" shares and you do not sell for a certain period you will pay no sales load." This is a truthful but deceptive and incomplete statement because although there is technically no front-end sales load, there is a commission and the customer pays for it. Problems arise when uninformed investors are tricked into believing that they are getting something for nothing, i.e., buying a fund without a sales commission as long as they hold it for a specified period. The broker gets

149. Senator Peter G. Fitzgerald, Statement on S. 2059, the Mutual Fund Reform Act of 2004, at 6 (Mar. 31, 2004), http://www.banking.senate.gov/public/_cache/files/a553f77492aa-40b2-9ef9-7969cb3b5c3d/33A699FF535D59925B69836A6E068FD0.fitzgerald.pdf [https://perma.cc/BAQ4-EPHJ] [hereinafter Fitzgerald Statement].

150. Freeman, supra note 38.

151. Id. at 763 .

152. Id. at 765 . 
the commission, and the customer pays it over time in the form of distribution fees. Don Phillips, Morningstar's Managing Director, has commented:

What I think is right with the negative opinion about $12 \mathrm{~b}-1$ fees is this hugely complicated selection process of a mutual fund. And it allowed the fund industry to create or to carry out something that frankly was unfair. The notion that "B" shares were no-load funds. I've talked to thousands of investors literally who came to me and said, "I bought a no-load fund." And then you ask them what they bought, and they bought the "B" shares of a load fund organization. They thought they were getting something for free. ${ }^{153}$

Former SEC Chairman Levitt had some words of wisdom for investors in his book, written after his tenure at the SEC:

Naturally, investors don't like it when funds skim 5 percent of their savings right off the top. So fund companies have figured out ways to hide some of the load by assessing annual fees that you pay as a percent of your assets in the fund. This is called a "distribution" fee, or a 12b-1 fee, after the Investment Company Act rule that governs such fees.... You should avoid owning shares in a fund that charges these fees . . ${ }^{154}$

There are other problems with CDSCs. One is that the loans supporting the upfront payment of sales commissions span multiple years yet fund boards and trustees must certify yearly that the program benefits the fund and its investors. A board could hardly de-certify a program and cause a default on the loans being supported by the CDSCs.

Freeman documents other abuses associated with CDSCs. One is that the investors are sometimes not offered the best deal where loads are concerned. Most front load funds have breakpoints in their fees schedules where the percentage commission is reduced as the amount of money invested increases. Typically, "B" shares or back load fund classes do not have such breakpoints. It is not unknown for brokers to sell B shares in amounts that come close to, but do not exceed, the breakpoints on front load funds. The reduction in commission resulting from a few more dollars in a load fund is thus avoided, and the broker earns a higher percentage commission. ${ }^{155}$

153. Mercer Bullard, The Mutual Fund Summit Transcript, 73 Miss. L.J. 1153, 1187 (2004) (remarks of Don Phillips, Managing Director of Morningstar, Inc.) (giving a panelist answer to a question at Mutual Fund Summit).

154. LEVITT, supra note 136, at 47-48.

155. Freeman, supra note 38 , at 763. 
Freeman also documents how some funds continue to charge 12b-1 fees on back load funds even though the loan supporting the original commission has been discharged. ${ }^{156}$ Moreover, some funds continue to charge 12b-1 shareholder service fees even though the fund is closed to new investors. It is difficult to see how current shareholders should be charged an ongoing fee to attract new investors when the fund is closed to new investors. ${ }^{157}$

The twenty-five basis point shareholder service fee is also being used for purposes not envisioned when the original rule was put in place. It has become common for the fee to be used to pay for inclusion of the fund(s) in online Mutual Fund Supermarkets. Fund sponsors derive the benefits of increased assets on funds sold through supermarkets and fund sponsors should bear the costs. ${ }^{158}$

Finally, it is useful to consider: what is a "distribution fee?" The very name of the charge is ambiguous and lacks descriptive clarity. A more descriptive label would have been "marketing fee," and it is curious that the SEC disguised the fee from the beginning.

In 2010, the SEC published a proposed new rule for mutual fund distribution fees, apparently in response to the ongoing criticism of $12 \mathrm{~b}-1$ fees. In the proposed new rule, the SEC took the step of re-naming the fee, now to be called the $12 \mathrm{~b}-2$ fee. Aside from mostly cosmetic changes, the new rule leaves $12 \mathrm{~b}-1$ essentially unchanged. ${ }^{159}$ Moreover, the few changes that could have an impact have yet to be implemented because, for unknown reasons, the proposed new rule is in limbo.

Before proposing the new rule, the SEC solicited the views of investor advocates, fund industry representatives, independent directors, and representatives from broker dealers and other intermediaries. A roundtable discussion was held on June 19, 2007. ${ }^{160}$ The new rule was heavily influenced by the results of that discussion.

156. Id. at 806 .

157. Id. at 781-82.

158. Howard M. Friedman, Securities Regulations in Cyberspace $§ 9.02$ (2015).

159. Mutual Fund Distribution Fees; Confirmations, 75 Fed. Reg. 47,064, 47,074 (proposed Aug. 4, 2010). See Jack W. Murphy et al., SEC Proposes Changes to Structure for Mutual Fund Distribution Fees, Dechert OnPoint (Aug. 5, 2010), https://www.dechert.com/SEC_Proposes_Changes_to_Structure_for_Mutual_Fund_Distribu tion_Fees_08-05-2010/[https://perma.cc/2VSU-4L8T] (discussing the proposed rules).

160. See Commission Roundtable on Rule 12b-1, U.S. SEC. \& ЕхсH. Сомм'N (Jun. 19, 2007), http://www.sec.gov/spotlight/rule12b-1.htm [https://perma.cc/UJ98-DCVK] (providing links to various materials relating to the rule 12b-1 Roundtable); see also 2007 Commission Roundtable Unofficial Transcript, U.S. SEC. \& Ехсн. Сомм'N (Jun. 19, 2007), https://www.sec.gov/news/openmeetings/2007/12b1transcript-061907.pdf

[https://perma.cc/P9GE-MMAM] (providing an unofficial transcript of the Jun. 19, 2007 commission roundtable) [hereinafter Commission Roundtable Transcript]. 
A central theme of the roundtable and the proposed rule is the role of $12 \mathrm{~b}-1$ fees as they support CDSCs. The ICI or industry position was that CDSCs are a convenient way for investors to decide how they want to compensate investment professionals to aid them in their mutual fund choices. According to the industry, informed investors can either pay a front load or choose to spread the cost over time by paying increased distribution fees. ${ }^{161}$ There are problems with the industry position. An investor sophisticated enough to actually balance the trade-off between front load and back or level load funds is smart enough to know that paying loads of any sort is inferior to no load alternatives. In essence, if investors need brokers to recommend funds, they are probably not sophisticated enough to make an informed choice about sales charges.

Some roundtable participants questioned whether investors are aware of and make informed choices about the services they pay for through $12 \mathrm{~b}$ 1 fees, "which many panelists agreed lacks the prominence of a front-end load." ${ }^{162}$ Industry representatives asserted that many investors prefer to pay sales charges over time rather than up front. ${ }^{163}$ Some roundtable participants called for outright abolition of CDSCs. ${ }^{164}$ In the discussion the SEC acknowledged some of the problems of $12 \mathrm{~b}-1$ fees: "Moreover, the rule has confounded many investors who remain unsure what a ' $12 \mathrm{~b}-1$ fee' is, how it impacts their account, and whether they should be willing to invest in a fund that imposes such a fee." 165

Given that the SEC itself found that many investors are confused about 12b-1 fees and some investors are duped into purchasing funds with CDSCs, it would seem that a regulator focused on protecting investors would abolish CDSCs. In a clear win for the industry, the SEC decided otherwise:

We do not believe that it would benefit fund investors to return to the era in which they paid a substantial front-end sales load and did not have access to various alternative forms of distribution payment arrangements. Denying investors the ability to select alternative distribution methods or to pay for distribution services over time is not the goal of this rulemaking. ${ }^{166}$

161. Commission Roundtable Transcript, supra note 160 , at 88 .

162. Mutual Fund Distribution Fees; Confirmations, 75 Fed. Reg. at 47,072.

163. Id.

164. Id. at 47,073 .

165. Id. at 47,075 .

166. Id. at 47,074 . 
This pathetic rationale for not addressing CDSCs is in substance a capitulation to the fund industry and exemplifies the industry's capture of the SEC. ${ }^{167}$

The proposed new rule jettisoned the need for special board findings, a written 12b-1 plan and an annual renewal of the plan, thus eliminating the charade necessitated by annual certification by the board that the plan benefited both the fund and shareholders.

One provision could have a salutary effect. The annual twenty-five basis points shareholder service fee is now to be explicitly labeled the "marketing and service fee." 168 In addition, the fees supporting CDSCs are now to be explicitly listed as the "ongoing sales charge."169 This would be a step in making clear and transparent the true nature of distribution fees. Unfortunately, six years have passed since the SEC "proposed" new rules and the changes have yet to be implemented.

The failure to eliminate or significantly reform the distribution fee mess is clear evidence of regulatory capture of the SEC. As Freeman so aptly opined: "A simple, naïve concept has evolved into something seriously flawed, if not grotesque." 170

\section{Soft Dollars Commissions}

In 1986, the SEC loosened its interpretation of Section 28e to permit a wider range of permissible uses of soft dollars, including "mixed-use" products and services that covered both research and administrative costs (e.g., computer hardware, communications equipment, and publications). ${ }^{171}$ Investment management firms were thus able to avoid significant administrative costs and further enhance profitability at the expense of fund shareholders. ${ }^{172}$

In a 1998 Inspection Report, the SEC found that "a significant number of broker-dealers (35\%) and advisers (28\%) provided and received non-

167. Note the use of the term "substantial" when associated with front load funds with the implication that CDSCs are not substantially equivalent or larger. Over time, there are no substantive differences in sales loads paid between front load and spread load fund classes. Thus, it is false and disingenuous in the extreme to characterize front loads as "substantial" because it implies that spread loads are lower and insubstantial. This is a subtle but telling indication of the Commission voicing industry talking points and absorbing the industry world view.

168. Mutual Fund Distribution Fees; Confirmations, 75 Fed. Reg. at 47,074.

169. Id.

170. Freeman, supra note 38, at 804 .

171. Securities; Brokerage and Research Services, Exchange Act Release No. 23,170, 51 Fed. Reg. 16,004 (Apr. 23, 1986).

172. See, e.g., William A. Birdthistle, Compensating Power: An Analysis of Rents and Rewards in the Mutual Fund Industry, 80 TuL. L. REV. 1401 (2006). 
research products and services in soft dollar arrangements." ${ }^{173}$ Instead of taking steps to reduce abuses the report concluded that the SEC "should reiterate and provide additional guidance," "consider adopting recordkeeping requirements," "require more meaningful disclosure," and "encourage firms to adopt internal controls." impressed: "Instead of protecting investor interests, the SEC defended Wall Street's gravy train."

In 2001, the SEC issued a release ${ }^{176}$ that extended the safe harbor beyond commissions associated with agency trades to include fees paid on riskless principal transactions and that benefitted brokers and fund sponsors at the further expense of fund shareholders.

The net effect of the loosening of standards was that fund managers were able to further enhance profits because they could lay off even more expenses on fund shareholders. As Marianne Jennings has put it:

The assumption on the benefits arguments was that the dollars above normal commissions were indeed providing return for the clients because of their use for insight and research. The problem was, well, that it all depended on the meaning of the term "research." Further exploration of the pass-along arrangements and the steep commissions revealed that research provided to the money managers from the broker/dealers included

- Computers (can't use Excel spreadsheets without a computer)

- Trips and conferences (in theory to sit and learn about the research but which, in practice, involved posh resorts and much golfing)

- Tickets to sporting events (what better forum for learning the latest in market trends?)

- Gifts, gifts, gifts

- Sometimes gifts in the form of cash

In short, the soft dollars allowed a great deal of "stuff" to flow to money managers from firms that had an interest in more and more trades executed at the direction of more and more money managers who were drawn to the broker/dealer firms not by their

173. Office of Compliance, Inspections and Examinations, U.S. Sec. \& Exch. COMMISSION, InSPECTION REPORT ON THE SOFT DOLlar PRACTICES OF BROKER-DEALERS, INVESTMENT ADVISERS AND MUTUAL FundS 3 (1998), https://www.sec.gov/ news/studies/softdolr.htm [https://perma.cc/MHK8-SG7V].

174. Id. at 2 .

175. SWENSEN, supra note 112, at 292.

176. Commission Guidance on the Scope of Section 28(e) of the Exchange Act, Exchange Act Release No. 45,194 (Dec. 27, 2001), 67 Fed. Reg. 6 (Jan. 2, 2002), https://www.sec.gov/rules/interp/34-45194.htm [https://perma.cc/9XQW-H9U9]. 
crackerjack research but rather by their ability to come up with the most "research," or perhaps the most creative and rewarding ways of conveying "research."

....

Management of conflicts of interest is not difficult because there are only two solutions: Don't do it, or disclose it. ${ }^{177}$

In the early 2000s, pressure built to either eliminate soft dollars or disclose them fully. The 2003 GAO study ${ }^{178}$ recommended disclosure, as did the CFA Institute. ${ }^{179}$

In the wake of the late trading market timing scandals of 2003, the U.S. House of Representatives passed a bill with overwhelming bi-partisan support that would, among other things, have eliminated soft dollars. ${ }^{180}$ The Senate Committee on Banking, Housing and Urban Affairs held extensive hearings on mutual fund reform. ${ }^{181}$ The Committee heard from many witnesses, including Benn Steil, a senior fellow at the Council on Foreign Relations, who testified that the soft dollar loophole "has given rise to a vast industry-wide kickback scheme through which fund managers use institutional brokers to transfer fundholder assets to themselves in a manner totally invisible to the fundholders." 182 The House bill and a similar Senate bill failed in the Senate Banking Committee, as discussed in Part V and VI.

In 2004, a NASD (now FINRA) Task Force, whose members included substantial industry representation, issued a report on soft dollars recommending that the SEC retain the soft dollar exemption but require significant disclosure of soft dollar arrangements to funds boards and shareholders. ${ }^{183}$

177. Marianne M. Jennings, Come See the Harder Side of Soft Dollars, 11 CORP. FIN. Rev. 44, 45-46 (2007). However, note how Ms. Jennings's insights are cogent but incomplete. There is a common misconception that the problem with soft dollars is that they are used to pay for non-research activities as if research is somehow appropriate. Since research is properly an expense of the fund manager, paying above-market rates on commissions bundled with research benefits the advisor at the expense of investors.

178. U.S. Gen. Accounting Office, GAO-03-763, Mutual Funds: Greater Transparency NeEDED IN Disclosures TO INVESTORS 56-57 (2003), http://www.gao.gov/assets/240/238496.pdf [https://perma.cc/AHQ8-BWMZ].

179. Soft-Dollar Standards: Guidance for Ethical Practices Involving Client Brokerage, CFA Inst. 7-9 (Nov. 2011), http://www.cfapubs.org/doi/pdf/10.2469/ccb.v2004.n1.4005 [https://perma.cc/JT89-KVWH].

180. Mutual Funds Integrity and Fee Transparency Act of 2003, H.R. 2420, 108th Cong. (2003).

181. Review of Current Investigations and Regulatory Actions Regarding the Mutual Fund Industry: Hearings Before the S. Comm. on Banking, Hous., \& Urban Affairs, 108th Cong. (2004).

182. Id. at 787 (statement of Benn Steil, Ph.D., André Meyer Senior Fellow in International Economics, Council on Foreign Relations).

183. Report of the Mutual Fund Task Force: Soft Dollars and Portfolio Transaction 
In a move to preempt full disclosure of soft dollars, the ICI urged the SEC to issue new interpretive guidance and rules for soft dollars payments and the safe harbor:

The ICI believes that the SEC should issue a new interpretive release that, for purposes of Section 28(e), excludes from the definition of "brokerage and research services" the following: (1) computer hardware and software, and other electronic communications facilities, used in connection with trading or investment decision-making; (2) publications, including books, periodicals, newspapers and electronic publications, that are available to the general public; and (3) third-party research services .... ${ }^{184}$

In 2006, the SEC issued new interpretative guidance for soft dollars that significantly tightened the rules for allowable soft dollar expenses. ${ }^{185}$ The rules largely followed ICI recommendations but did not require enhanced disclosure of soft dollar commissions. ${ }^{186}$ The ICI's gambit was thus successful. ${ }^{187}$

There followed a rather curious incident. Christopher Cox, Chairman of the SEC and former congressman, made efforts to ban the use of soft dollars. In a move that made it clear that he spoke as an individual and not as Chairman of the SEC, Cox sent a letter to Senate Banking Committee

Costs, NAT'L ASS'N OF SEC. DEALERS (NASD) 5 (2004), http://www.finra.org/ sites/default/files/Industry/p012356.pdf [https://perma.cc/XVW2-WTJG].

184. Letter from Matthew P. Fink, President, Inv. Co. Inst., to William H. Donaldson, Chairman, U.S. Sec. \& Exch. Comm'n, Request for Rulemaking Concerning Soft Dollars and Directed Brokerage (Dec. 16. 2003), https://www.sec.gov/rules/petitions/petn4-492.htm [https://perma.cc/VJ9D-88MG].

185. Commission Guidance Regarding Client Commission Practices Under Section 28(e) of the Securities Exchange Act of 1934, Exchange Act Release No. 54,165 (July 18, 2006), 71 Fed. Reg. 41,978 (July 24, 2006). See SEC Releases New Interpretive Guidance on Soft Dollar Arrangements, DECHERT OnPOINT (Aug. 2006), https://www.dechert.com/ files/Publication/bc1b1796-285c-4fd6-93fd-2d089e30e09e/Presentation/ PublicationAttachment/2e4311fb-8238-4f41-91fa-2d9de9287df8/FS_Update11_8-06.pdf [https://perma.cc/7GWY-NNTV] (explaining the guidance and providing context).

186. Id.

187. The industry has incentives to keep soft dollar commissions opaque. See Roger Edelen, Richard Evans \& Gregory Kadlec, Shedding Light on "Invisible" Costs: Trading Costs and Mutual Fund Performance, 69 FIN. ANALYSTS J. 33 (2013) (explaining that investment funds benefit from less soft dollar disclosure). For example, Edelen finds that soft dollars for research are more negatively related to fund performance than expensed research for similar services). For each ten basis point increase in the cost of bundled soft dollar commissions, fund performance declines by a statistically significant twenty-one basis points. Moreover, mutual fund investors respond differently to soft dollar commissions than to expensed research payments. Expensed research is transparent and has a negative impact on inflows from investors. In contrast, soft dollar commissions are opaque and have a positive impact on investor inflows. 
Chairman Christopher Dodd, and House Financial Services Committee Chairman Barney Frank, in which he suggested that a "legislative fix" might be warranted with regards to the soft dollar issue. ${ }^{188}$ Cox elaborated his views in a speech in New York, as reported by Reuters:

Soft-dollar deals - where money managers pay inflated commissions to get favors such as free stock research from brokerages - need tighter regulation, the top U.S. market regulator said on Thursday.

Securities and Exchange Commission Chairman Christopher Cox vowed to push Congress to reform or even repeal laws that allow soft-dollar transactions, which some critics say present conflicts of interest and cheat investors.

"Soft dollar needs to see the light of day," Cox said in a speech to the National Italian American Foundation.

"This witch's brew of hidden fees, conflicts of interest and complexity of application is at odds with the investor's best interest." 189

Mr. Cox's candor and clarity were commendable but ultimately failed as Congress did not act on his proposal. The unusual incident speaks to a split within the SEC. Mr. Cox clearly did not have the votes to, at a minimum, force additional disclosure of soft dollars. Given the pressure to reform or eliminate soft dollars from the GAO, CFA Institute, Congress, and the NASD Task Force, the Commission chose to stand pat and tinker around the edges of allowable soft dollar expense categories in yet another example of narrow regulatory capture.

Soft dollars continue to be legal. This clear conflict of interest on the part of the fund sponsors costs fund shareholders hundreds of millions of dollars each year.

\section{Disclosure of Trading Costs}

In addition to percentage annual expenses disclosed in the Expense Ratio, there are other very substantial expenses that are undisclosed. When a mutual fund trades securities, trading costs (the sum of brokerage commissions, bid-ask spreads, and the market impact of trades) are added to the cost of purchases or deducted from the proceeds of sales. These costs are material but are not included in expense ratios.

188. Judith Burns, Cox Vows to Penetrate Soft-Dollar "Fog"; SEC Chairman Urges Congress to Eliminate Fee-Research Bundling, WALL ST. J., May 31, 2007, at C15.

189. Joseph Giannone, SEC Head Urges Crackdown on "Soft Dollar" Deals, REUTERS Bus. News (May 31, 2007, 4:45 PM), http://www.reuters.com/article/businesspro-secsoftdollars-dc-idUSN3122527720070531 [https://perma.cc/VXT7-TSF9]. 
Over the period 1996 to 2009, the average management fees (a subset of the total expense ratio) paid by U.S. equity mutual funds were $0.73 \%$ of TNA (Total Net Assets), while the average brokerage commissions were $0.33 \%$ of TNA. ${ }^{190}$ These results are similar to findings by Livingston and O’Neal. ${ }^{191}$

Brokerage commissions understate actual trading costs because they ignore bid-ask spreads and the impact of trades on the price of the security. Because mutual funds trade in large blocks, the market impact costs are substantial. Edelen, Evans, and Kadlec found average expense ratios of $1.14 \%$ and trading costs of $1.44 \%$, which generate a total drag on returns of about $2.6 \% .^{192}$ The findings from Edelen et al. are startling: mutual fund trading costs are higher on average than expense ratios but are undisclosed. ${ }^{193}$

The SEC is well aware of these costs. In the wake of the mutual fund scandals in the early 2000s, both the House and Senate held extensive hearings and produced legislation to reform the industry.

The U.S. House of Representatives overwhelmingly passed H.R. 2420, the Mutual Fund Integrity and Fee Transparency Act of 2003, requiring funds to reveal some of the costs. ${ }^{194}$ The bill mandated disclosure of brokerage commission per $\$ 1,000$ of assets, turnover ratios compared among investment companies, and soft dollar arrangements. ${ }^{195}$ In addition, the bill contained provisions to eliminate the late trading, market timing, and other abuses revealed in the scandal. ${ }^{196}$ In regards to trading costs, the bill required that the SEC issue a concept release examining transactions costs incurred by investment companies including commissions, spread, and market impact costs. ${ }^{197}$

The House vote took place on November 19, 2003. On December 18, 2003, the SEC issued a concept release in response to the House mandate. ${ }^{198}$ The concept release is an exemplary exploration of the issues

190. Monika K. Rabarison, New Insights into Mutual Fund Brokerage Commissions, 40 J. ECON. \& Fin. 492, 493 (2016).

191. Miles Livingston \& Edward S. O’Neal, Mutual Fund Brokerage Commissions, 19 J. Fin. RESEARCH 273 (1996).

192. Edelen et al., supra note 187 , at 33-44.

193. Brokerage commissions, but not market impact costs, are disclosed in the Statement of Additional Information, a report of which few investors are aware.

194. Mutual Funds Integrity and Fee Transparency Act of 2003, H.R. 2420, 108th Cong. (2003). H.R. 2420 passed on a vote of 418 to 2 with fourteen members not voting. Tom Nohel et al., infra note 211.

195. H.R. 2420 § 101(a).

196. Id. § 206.

197. Id. § 101(c).

198. Request for Comments on Measures to Improve Disclosure of Mutual Fund Transaction Costs, 68 Fed. Reg. 74,820, 74,821 (Dec. 24, 2003). 
associated with mutual fund trading costs. The release invites comments and states that:

The Commission is aware of the need for transparency of mutual fund fees and expenses and committed to improving disclosure of the costs that are borne by mutual fund investors; but it is mindful of the complexities associated with identifying, measuring, and accounting for transaction costs. Thus, the Commission is considering how mutual fund transaction cost disclosure requirements should be revised to provide more meaningful information to fund investors. In particular, the Commission is considering whether mutual funds should be required among other things to (1) quantify in some meaningful way and disclose some or all of their portfolio transaction costs without including these costs in their expense ratios and fee tables; (2) quantify some or all transaction costs and include them in expense ratios and fee tables; (3) provide other quantitative information about the level of transaction costs, or (4) some combination of the above. ${ }^{199}$

The House Bill was duly passed on to the Senate Banking Committee, where it subsequently died. With the death of the bill came the death of the SEC's interest in disclosing trading costs of mutual funds. Thus, it is impossible to argue that the SEC was, or is, unaware of the importance of the issue and the lack of disclosure.

Non-disclosure of trading costs is a serious issue. Similar to the nondisclosure of annual expenses, it hampers investors' ability to choose wisely among fund alternatives and increases the unsophisticated investor's dependence on the advice of investment professionals with conflicted interests. The industry and brokers who flog actively managed funds have good reason to mask the true costs of active management. The annual, allin costs of active management generate dramatic differences in investment outcomes compared to passively managed funds. Information that highlights these differences is an anathema to the investment management industry. Average expense ratios of $1.14 \%$ and trading costs of $1.44 \%$ generate a total drag on returns of about $2.6 \%$ percent. $^{200}$ Since low cost index funds are available with expense ratios in the neighborhood of ten basis points $(0.1 \%)$, actively managed funds on average may trail passively managed funds by about $2.5 \%$ annually.

Expense ratios and trading costs are not the only reasons that actively managed funds underperform passive management. These numbers fail to take into account the substantial amounts paid in front loads for actively

199. Id. at 74,821 .

200. Edelen et al., supra note 187. 
managed funds, as well as greater taxes incurred by actively managed funds because realized gains from trading flow through to fund investors. In addition, actively managed funds often carry substantial cash positions that are a net drag on performance.

John Bogle, founder of the Vanguard family of funds and an index fund pioneer, has estimated the all-in costs of actively managed mutual fund investing as compared to index or passive management. ${ }^{201}$ It should be emphasized, as Bogle does, that there is a substantial amount of imprecision involved in these estimates. Bogle makes conservative assumptions, especially where trading costs are involved, and estimates that all-in costs of an actively managed tax-deferred account are 2.21 percent higher than an indexed account. ${ }^{202}$ These estimates ignore the relative tax inefficiency of actively managed funds as compared to index funds.

Compounded over time, such differences have a dramatic impact on the retirement outcomes of a typical investor. Bogle assumes a thirty-yearold investor with a $\$ 30,000$ annual salary growing at 3\% per year and plans to retire at age seventy. ${ }^{203}$ The investor contributes $10 \%$ of his or her annual salary to a tax sheltered account. ${ }^{204}$ After forty years, the investor has accumulated $\$ 927,000$ on the indexed account versus $\$ 561,000$ in the account with actively managed funds. ${ }^{205}$ Assuming a $4 \%$ annual withdrawal rate, the investor in active funds could withdraw $\$ 1,870$ while the indexed investor would receive $\$ 3,090 .^{206}$

\section{FAILURE OF COMPREHENSIVE MUTUAL FUND REFORM LEGISLATION}

After extensive hearings in the Senate, Senator Peter Fitzgerald of Illinois introduced S. 2059, The Mutual Fund Reform Act of 2004. ${ }^{207}$ The bill mandated clear and comprehensive fund information, eliminated distribution fees and soft dollar commission arrangements, and included provisions to deal with market timing and late trading. ${ }^{208}$ The act was endorsed by Vanguard founder John Bogle, who characterized the bill " "as the gold standard in putting mutual fund shareholders back in the driver's

201. John C. Bogle, The Arithmetic of “All-In” Investment Expenses, 70 FIn. ANALYSTS J. 13 (2014).

202. Id. at 16 .

203. Id. at 17 .

204. Id.

205. Id.

206. Id.

207. Mutual Fund Reform Act of 2004, S. 2059, 108th Cong. $\S \S 210,310,311,312$, and 315 (2004).

208. Id. 
seat.",209 S. 2059 had twelve co-sponsors: seven Democrats and five Republicans. ${ }^{210}$ Thus, Senator Fitzgerald's bill had bi-partisan support in the Senate. However, the decision to bring the bill to a vote in the Senate Banking Committee depended on the sole discretion of the Chairman of the Committee, Senator Richard Shelby of Alabama. Senator Shelby failed to bring S. 2059 to a vote; thus, the bill died at the end of the $108^{\text {th }}$ Congress and along with it died the chance of comprehensive mutual fund reform. ${ }^{211}$ Senator Shelby rationalized the decision as a desire not to interfere with the efforts of SEC Chairman William Donaldson to reform the mutual fund industry. ${ }^{212}$

The website OpenSecrets.org publishes a list of the major donors for each member of congress, including Senator Shelby, the current and former Chairman of the Senate Banking Committee. ${ }^{213}$ In 2004, Senator Shelby's campaign committee raised $\$ 576,183$ in contributions from the Securities and Investment Industry. ${ }^{214}$ For 2016, the Securities and Investment Industry was the top industry contributor to his campaign committee, contributing $\$ 581,800$. $^{215}$

209. Fitzgerald Statement, supra note 149, at 2.

210. See Mutual Fund Reform Act of 2004, Co-sponsors, Congress.gov, https://www.congress.gov/bill/108th-congress/senate-bill/2059/cosponsors?resultIndex=20 [https://perma.cc/6VDC-NFQS] (listing the Senators sponsoring the bill: Sen. Levin (DMI); Sen. Collins (R-ME); Sen. Lugar (R-IN); Sen. Kennedy (D-MA); Sen. Hollings (D$\mathrm{SC})$; Sen. Lautenberg (D-NJ); Sen. Durbin (D-IL); Sen. Voinovich (R-OH); Sen. Coleman (R-MN); Sen. Cantwell (D-WA); Sen. McCain (R-AZ); Sen. Pryor (D-AR)).

211. Tom Nohel et al., Side-by-Side Management of Hedge Funds and Mutual Funds, 23 Rev. Fin. Studies 2342, 2343 n.4 (2010); Mercer E. Bullard, The Mutual Fund as a Firm: Frequent Trading, Fund Arbitrage and the SEC's Response to the Mutual Fund Scandal, 42 Hous. L. ReV. 1271, 1273 (2006).

212. See Rachel McTague, Mutual Funds: Donaldson, Shelby on Same Wave Length: SEC Able to Handle Mutual Fund Reforms, 36 SEC. REG. \& L. REP. (BNA) 661 (2004) (quoting Senate Banking Chairman Richard Shelby's statement that the SEC is "showing a lot of leadership and resolve.... We don't want to do anything that would be construed in any way as undermining what the SEC is doing."). SEC Chairman William Donaldson was co-founder and served as Chairman and CEO of the investment banking firm Donaldson, Lufkin \& Jenrette. SEC Biography: Chairman William H. Donaldson, U.S. SEC. \& ExCH. Cомм'N (Jan. 23, 2009), http://www.sec.gov/about/commissioner/donaldson.htm [https://perma.cc/9ABV-RNNS].

213. Sen. Richard C. Shelby, OPENSECRETS.ORG, http://www.opensecrets.org/ politicians/summary.php?cid=N00009920\&cycle=2016\#cont [https://perma.cc/KW28$\mathrm{J} 2 \mathrm{BH}]$.

214. Sen. Richard C. Shelby, OPENSECRETS.ORG, http://www.opensecrets.org/ politicians/summary. php?cycle $=2004 \&$ type $=I \&$ cid $=$ N00009920\&newMem $=$ N\#cont [https://perma.cc/98CU-Y57F].

215. Sen. Richard C. Shelby, OPENSECRETS.ORG, http://www.opensecrets.org/ politicians/summary.php?cycle=2016\&type $=I \&$ cid $=$ N00009920\&newMem $=$ N\#cont [https://perma.cc/9R57-TV8N]. 
It is impossible to know how much of an influence the investment management industry had on Senator Shelby's decision. What is clear is that because of large political contributions, the industry had a seat at the table and its voice was clearly heard. What is not so clear is why the interests of the investing public were ignored.

The investment management industry is adept at pulling the right levers to influence the political and regulatory process and, as demonstrated above, has done so repeatedly in regard to advisory and distribution fees and soft dollar commissions. The failure of comprehensive mutual fund reform in 2004 is yet another and recent example of broad regulatory capture.

\section{SUMMARY AND RECOMMENDATIONS}

Mutual funds are especially vulnerable to regulatory capture. Massive amounts of wealth are involved, the product is complex, and consumers are largely financially illiterate and under-informed. A relatively small number of fund sponsors are able to reap huge profits by overcharging a large number of consumers by small amounts each year. Because of compounding, the small increments of excess and often undisclosed costs have a large impact on the terminal value of mutual fund investments. Fund sponsors are thus incentivized to capture the regulators, and there are few incentives for consumers or consumer advocacy groups to respond. The Investment Management Industry has effectively captured the SEC and influential members of Congress.

The ultimate aim of the investment management industry was and is to influence regulation to enhance the profits accruing to the owners of the investment management firms. Each of the examples of broad and narrow regulatory capture illustrated directly or indirectly enhances the profits of those shareholders at the expense of mutual fund shareholders.

Advisory fees are too high because mutual funds are captives of the investment management firms that create and manage them. The industry successfully influenced Congress to neutralize the SEC in regard to such fees when the 1970 amendment to the Investment Company Act of 1940 was passed. Perhaps the single most significant action the SEC could do to help mutual fund investors would be to ignore the wording in the Senate Report accompanying the 1970 Act and use its standing to sue. It could and should pick one of the largest fund complexes with egregiously high fees and litigate an excessive fee case to its conclusion. The resultant precedent could lower advisory fees to the range of fees actually determined by arm's length bargaining and save mutual fund investors billions each year. 
This paper highlights the true nature of mutual fund distribution fees. The SEC was manipulated into imposing marketing fees on the assets of mutual fund shareholders. Marketing fees should properly be borne by the investment management firms that benefit from the increased level of fund assets. The SEC's continued refusal to rein in CDSC abuses is a disgrace. Mutual fund shareholders continue to be improperly charged billions each year. The SEC has within its authority to rescind Rule 12-1 and should do so immediately.

The SEC should also do everything in its power to minimize the impact of soft dollar commissions. Commissions at above-market rates currently finance research costs and other items that are properly expenses of investment management firms. Mutual fund shareholders are overcharged hundreds of millions of dollars per year in above-market commission rates, and this should cease. At a minimum, the SEC should immediately require full disclosure of all soft dollar arrangement by mutual fund investment management companies.

The SEC should require investment management firms to periodically disclose the dollar level of fees imposed on each shareholder of each mutual fund. In addition, estimates of trading costs including commissions, bids-ask spreads, and market impact should be included. The SEC's behavior in regard to cost disclosure is unconscionable.

The cumulative effect of the capture of the SEC is that the mutual fund investment management industry is hugely profitable. The universe of publicly traded fund sponsors is extraordinarily profitable and fund sponsors earn economic profits for their owners. ${ }^{216}$

In summary, this paper demonstrates that the Securities and Exchange Commission has been captured in both a broad and narrow context. In a broad sense, politicians have directly enabled the industry to siphon off billions in excess advisory and distribution fees and soft dollar commissions. In a narrow sense, the SEC has refused to reform distribution fees and has slow walked disclosure of fees and trading costs.

Professor Freeman's comments in the context of distribution fees aptly summarize the role of the SEC in the overall regulation of mutual funds:

After more than 60 years of intensive government regulation, we find the load mutual fund business sporting a dysfunctional governance model grounded on conflicts of interest, and a haphazard, costly distribution system where false labeling of expense items is rampant. The system is built on disproved hypotheses, hidden payoffs, and deceptive marketing ploys.

216. Stewart L. Brown, Gartenberg: Some Empirical Clarity 32 (June 9, 2015), http://ssrn.com/abstract=2616347, http://dx.doi.org/10.2139/ssrn.2616347, or https://perma.cc/4RKQ-BJ3W. 
Watching over it is a federal agency that functions more as the fund managers' crony than as a defender of the public good.... [A]ny change for the better for fund shareholders is not apt to come from the politically-influenced agency that ostensibly regulates the investment management industry. ${ }^{217}$

Senator Peter Fitzgerald's comments are especially cogent: "The mutual fund industry is now the world's largest skimming operation-a \$7trillion trough from which fund managers, brokers and other insiders are steadily siphoning off an excessive slice of the Nation's household, college, and retirement savings." 218

Since Senator Fitzgerald made his comments, mutual fund assets have more than doubled and the skimming and siphoning continues unabated. Individual investors are being systematically under-informed and overcharged billions and the Congress and SEC are complicit. In plain language, the ultimate cause of this disgraceful situation is the corruption of our institutions.

217. Freeman, supra note 38 , at 831.

218. Mutual Funds: Trading Practices and Abuses that Harm Investors: Hearing Before the Fin. Mgmt., The Budget, \& Int'l Sec. Subcomms. of the S. Comm. on Governmental Affairs, 108th Cong. 3 (2003) (statement of Senator Peter G. Fitzgerald). 